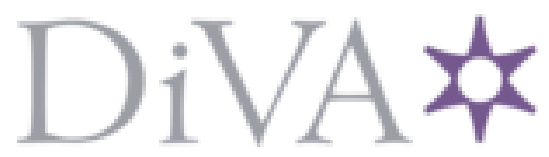

http://www.diva-portal.org

This is the published version of a paper published in European Journal of Law and Economics.

Citation for the original published paper (version of record):

Hall, T., Jörgensen, F. (2015)

Legal variation and capital structure: Comparing listed and non-listed companies.

European Journal of Law and Economics, 40(3): 511-543

http://dx.doi.org/10.1007/s10657-012-9359-7

Access to the published version may require subscription.

N.B. When citing this work, cite the original published paper.

Permanent link to this version:

http://urn.kb.se/resolve?urn=urn:nbn:se:su:diva-98050 


\title{
Legal Variation and Capital Structure: Comparing Listed and Non-Listed Companies
}

\author{
Thomas W. Hall and Fredrik Jörgensen
}

\begin{abstract}
We exploit the natural institutional variation in Western Europe to examine leverage (and debt maturity) for listed and non-listed companies (NLCs). We find that the legal efficiency measure (Djankov, et al, 2008) is more closely related to the amount of leverage and debt maturity than is the creditor rights score of La Porta, et al. (1996; 1997). One component of the standard measure of creditor rights was consistently and positively associated with leverage: whether secured creditors are paid first in the event of distress. Firms located in French and German legal family countries have less leverage than companies in common law setting, but Scandinavian firms have more. Asset specificity has a negative impact on leverage, but a positive impact on debt maturity. Finally, using a matched sample of otherwise similar privately held companies, we find that listed firms have less debt, consistent with a corporate governance interpretation that presumably more dispersed publicly traded firms are more likely to avoid the disciplining device of leverage. The findings are robust to use of industry-level fixed effects.
\end{abstract}

Keywords: legal origin, creditor rights, leverage, debt maturity

JEL Classifications: G32, G33, F30

Published in European Journal of Law and Economics November 2012. 


\section{Legal Variation and Capital Structure: Comparing Listed and Non-Listed Companies}

In this paper, we examine whether and how national-level institutions affect leverage (defined as long-term debt over total assets) and debt maturity (defined as long-term debt over total debt). Unlike many previous studies that focus exclusively on firms with equity listed on public markets (with presumably better relationships with capital markets), we include both listed and non-listed companies in our analysis. This is important when considering cross-country variation in firm-level financial behaviour, because unlisted companies are less likely to have access to international capital markets. It is likely that national-level institutions pose more binding constraints on the ability of such firms to raise external finance to fund growth above and beyond what is possible from retained earnings, or to adjust their capital structure to its ideal status.

Many previous studies have examined capital structure of firms in only one country, or have looked at listed firms in a variety of countries (Fan, et al. 2012; Song and Philippatos, 2004). An interesting global study provides detailed information provided by seasoned experts about how debt contracts are enforced in a procedural sense, but does not map this onto the actual behaviour of privately held companies (Djankov et al, 2008). Another recent study (de Jong, et al, 2008) finds that most of the country-level variation identified by previous work disappears when firm-, industry, and country-specific determinants are incorporated. That study does not examine privately-held companies, which are more likely than listed firms to be subject to segmented capital markets, and hence are more likely to be influenced by legal institutions in their country of operation. Giannetti, (2004) examines firm-level data from privately held companies, but only includes firms from two legal families (common law and French); therefore there is not sufficient variation to examine the impact of them on capital structure or other financial behaviour of firms.

We find that the legal efficiency variable from Djankov, et al. (2008) is more closely related to actual leverage and debt maturity than are the various creditor rights scores of La Porta, et al. (hereafter, LLSV; 1996, 1997). It is important to 
consider this variable because it is so widely cited in the literature. ${ }^{39}$ One component of the CRED score was consistently and positively associated with leverage: whether secured creditors are paid first in the event of distress. Firms located in French and German legal family countries have less leverage than companies in common law setting, but Scandinavian firms have more; the results for debt maturity mirror these findings. Asset specificity has a negative impact on leverage, but a positive impact on debt maturity. Finally, using a matched sample of otherwise similar privately held companies, we find that listed firms have less debt, consistent with a corporate governance interpretation that presumably more dispersed publicly traded firms are more likely to avoid the disciplining device of leverage. The findings are robust to use of industry-level fixed effects.

The paper proceeds as follows. Section 1 provides a brief literature review to motivate our research questions. Section 2 describes the data and models we employ; statistical results are given in Section 3. The conclusion is presented in Section 4.

\section{International Studies of Capital Structure and Debt Maturity}

A very large literature using country-level macroeconomic data and firm-level data for publicly listed companies finds that creditor rights are associated with leverage and the maturity structure of debt. Examination of non-listed companies (NLCs), however, provides an out-of-sample test of these findings, and is relevant because smaller firms are more likely to face capital constraints relative to large, listed companies.

Previous studies have examined leverage in a comparative context, often employing country-level information (Aggarwal and Jamdee, 2003; Demirgüç-Kunt and Maksimovic, 1998, 1999, 2002; Booth, et al, 2001; Schmuckler and Vesperoni, 2000; La Porta, et al, 1998, often abbreviated as LLSV). Demirgüç-Kunt and Maksimovic (2002) mention one disadvantage of using a firm-level approach: data on relatively few companies can be used because of a typical reliance on publicly traded entities. To overcome this research obstacle, we employ tens of thousands of firmyear observation from a large number of unlisted companies, and compare them with listed firms. An advantage of using disaggregated data, however, is that we are able to control for firm-level variation (Fan, Titman, and Twite, 2003; Wald, 1999; Hall and Joergensen, 2008; Hall, 2011) in things like asset tangibility, return on assets,

${ }^{39}$ A recent search on the social science research network led to over 980 hits for the search word "investor rights" and over 300 hits for the search term "creditor rights". The LLSV papers are widely cited as the seminal works in the so-called law-and-finance stream of literature. 
effective tax rates, and firm size (here, natural log of total assets). An advantage of our approach is that we are able to include firms with as few as 100 employees, which allows us to examine capital structure choices in relatively small firms.

A groundbreaking global analysis of typical bankruptcy procedures (Djankov et al, 2008) considers national variation in the resolution of a hypothetical, distressed, privately-held firm (a medium-sized hotel). That analysis incorporated expert opinion in a large number of countries concerning a very simple hypothetical distressed firm situation. The hypothetical firm had only one creditor and a relatively straightforward capital structure. The case was designed to limit the complexity that could confront analysis of a hypothetical bankruptcy case. The study makes clear that large, publicly traded firms would face more complex legal procedures surrounding distress; this fact calls into question any unreflective application of their findings to the case of listed companies. Because their study uses a hypothetical case tailor-made to examine distress and bankruptcy (and, by extension, collateral and lending aspects of external finance, the central concerns of our paper), it makes sense to ascertain whether their findings shed light on (1) the leverage of observed listed vis-à-vis non-listed firms, and (2) the leverage of firms located in different countries, with different national institutions concerning the ability of a creditor to perfect a claim on pledged assets.

In fact, examination of privately held firms and their financial behaviour is an important yet very rarely studied aspect of the finance (and, by extension, law-andfinance) literature. Our study is in line with some recent examinations that contrast publicly traded and privately held firms to determine whether and how ownership (and the decision between public and private status) affects financial performance. Beck, et al. (2002 and 2004) shows that large, publicly-held firms are not fully representative of the legal constraints that face unlisted companies. Looking at US firms, Asker, et al. (2011) finds that publicly traded firms invest less and are less responsive to changes in investment opportunities vis-à-vis otherwise similar privately held companies. A contrasting result was found by Martal and Reisel (2009) who use the same data source that we do, and find that there is no substantial difference between privately held and publicly traded firms in terms of investment behaviour. Sheen (2009) contrasts the investment behaviour of privately held vis-àvis publicly traded companies, again in the US context. Our study constitutes an extension of this unresolved issue in the literature on ownership and performance, but regarding leverage and debt maturity as opposed to investment behaviour. In addition, it extends the analysis to incorporate European firms, which allows us to exploit the natural variation in institutional environments (legal family, creditor rights, efficiency of bankruptcy procedures) there. 
Finally, one important issue that has been under-studied in the literature on leverage relates to how institutional variation interacts with the "specificity" of fixed assets, which affects their liquidation value and use as collateral (Acharaya, et al. 2004). Firms in industries with highly "specific" assets possess property, plant, and equipment that is relatively illiquid vis-à-vis other industries. According to that study, asset specificity also may be indicative of credit-friendliness in the country's legal systems-firms with high asset specificity in an equity-friendly environment use more leverage than in a debt-friendly environment. A follow-up study (Acharaya et al. 2008) examines the relationship between national institutions (bankruptcy codes) and leverage, but only considers the case of publicly traded firms in the US and UK. We examine this issue, but in the context of privately held firms that presumably face additional credit constraints relative to publicly traded firms.

In addition to examining leverage in this paper, we consider also the level of debt maturity (measured as long-term debt over total debt). Perhaps there are differences between the ability of privately held firms to access longer term debt, due to lack of good relationships with capital markets. Thus, the key questions we consider are:

$>$ Is there any relationship between ownership (public/private status) and capital structure?

$>$ Do institutions (such as legal origin and creditor rights) matter for leverage and debt maturity, and if so which are most important?

$>$ How does the specificity of fixed assets affect the ability of firms to borrow, and to borrow at longer maturities?

\section{Data and Models}

\section{A. Data and Descriptive Statistics}

Globe-spanning studies face problematic research questions related to substantial variation in economic development and sophistication of national financial markets. We constrain our study to only include the relatively homogenous countries of Western Europe, where issues concerning dividend imputation, the role of institutional investors and informational intermediaries, and life insurance penetration are less likely to distort our data than for the global, cross-sectional approach of Fan, Titman, and Twite (2003). Differences in accounting treatments are less likely to confront our data compared to previous studies, due to the data cleansing and standardization methods performed by our data source (Bureau van Dijk's Amadeus data set) and the fact that all firms report using the IFRS accounting standards. Finally, inflation and other variations in macroeconomic performance 
were not major considerations during the period we consider, so problems related to firm-level data from, e.g., Turkey that encompass problematic accounting treatments of hyper-inflationary effects as in Demirgüç-Kunt and Maksimovic (2002) are not relevant for our analysis. ${ }^{40}$

Therefore, to conduct our empirical tests, we employ the Amadeus database (data from the years 1995 - 2001 were available to us) that covers firms in most of Western Europe. ${ }^{41}$ Amadeus data on Western European countries are analyzed by Gianetti, 2004, but she only examines firms from two legal families (Common and French; Table 5 in that study), which we extend by considering firms from both German and Scandinavian legal origin settings.

We eliminate all firms with no reported SIC code and all firms with SIC codes beginning with a 6 (including financial services). ${ }^{42}$ To be consistent with previous leverage studies, we further narrow our data set following the SIC code selection of Fan, Titman, and Twite (2003), and include only firms with codes as follows: business services (SIC 73), chemicals (SIC 28), construction (SIC 15, 16, 17), food and beverage (SIC 20), communication (SIC 48), metal fabrication (SIC 33, 34), resources (SIC 10, 12), newspapers (SIC 27), paper and pulp (SIC 26), wholesale (SIC 50, 51), and retail (SIC 52-59). Finally, we truncated (see Frank and Goyal, 2005) the data set to eliminate 25,597 firm-year observations that had negative book value of equity. Finally, in order to eliminate some extreme values and ensure that our findings were not being driven by outliers, we windsorized several variables (long-term debt over total assets, long-term debt over total debt, effective tax rate, and return on assets ${ }^{43}$. To ensure no loss of observations (Frank and Goyal, 2005), we replaced outlier values with more reasonable values at the $1 \%$ and $99 \%$ level for ROA and effective tax rate, and windsorized the dependent variables based on the balance sheet realities (e.g., such that total debt could not be greater than long-term debt, and for reasonable values of ROA and effective tax rate).

Following these procedures, we are left with a sample indicated in Panel A of Table 1. Panel B of Table 1 presents descriptive statistics for the two dependent

\footnotetext{
40 In addition, we checked national variations from IAS Plus accounting standards and found no major discrepancies that should be driving our results (Deloitte and Touche, 2000).

${ }^{41}$ For analysis of the Eastern European firms in that data set, see Klapper, et al, 2002; Hall and Jörgenson, 2008; Hall, 2011.

42 The version of the Amadeus database we use includes firms with operating revenue in excess of $€ 10$ million, or total assets above $€ 20$ million, or 100 or more employees.

${ }^{43}$ Long-term debt over total debt was windsorized at the value of $95 \%$, long-term debt over total debt was windsorized at $100 \%$, return on assets was windsorized at -0.266 and 0.261 (the $1 \%$ and $99 \%$ values, respectively), and effective tax rate was windsorized at -3.55 and 4.29 , (again the 1\% and $99 \%$ values).
} 
variables in our study. We possess a large number of observations from each legal family, but it should be noted that we lack data from the income statement for Irish companies (one of only two common law countries along with the United Kingdom). Therefore, in many of the specifications, we alternate between estimations that include these variables and those that exclude them; by including ROA and Efftax, we have more control variables included in the statistical analysis, but by excluding them we obtain more observations. Because we only have data from two common law countries, inclusion of the Irish data allows us to provide something of a robustness check on whether our common law findings are in fact solely driven by observations from the UK. In this context, it should be noted that the UK is a much larger jurisdiction with many more firm-year observations.

We are aware of the findings of de Jong et al. (2008) that firm-level determinants of leverage vary by country, and for this reason conduct some countrylevel regressions for leverage (and debt maturity). Nevertheless, we are interested in the firm-level effect of country-level variation in legal origin and creditor rights. Given that we only had a limited number of countries in our analysis, it was necessary to pool firm-level observations from different countries. In the spirit of their argument, we also performed tests where firm-level data from the same legal family were pooled. We attempted to include country-level dummy variables, but this was not always possible in some specifications because there were high levels of correlation between creditor rights and legal origin.

Quite a lot of univariate variation exists in the sample, such that the average amount of leverage varies from a high of $27 \%$ (Iceland) to a low of six-tenths-ofone-percent (Italy). For debt maturity, the country with firms that have the highest average maturity (equally-weighted) is Iceland (43\%), and the country with the shortest debt maturity is Italy, where only $1 \%$ of its total debt was long-term debt. There is no obvious univariate relationship between legal origin and levels of either debt or maturity, which motivates our multivariate examination, below.

\section{B. Empirical Tests and Models}

We perform a number of empirical estimations related to leverage, creditor rights, and legal origin. Our data are in unbalanced panel form (motivating our decision to use generalized least squares or GLS to control for correlation among observations of the same firm), such that not every firm-year observation will have data for all variables, in which case that observation will be dropped from the estimation. Because we are interested in how national characteristics (e.g., creditor 
rights and legal origin) affect managerial decisions, but also with firm-level variation, we do not use firm-level fixed effects but rather use random effects. Otherwise, we could not include in the analysis variables such as asset specificity or even creditor rights and legal origin (or SIC codes or asset specificity) that do not vary over time at the firm level.

\section{Leverage and Creditor Rights}

We consider both the leverage (long-term debt over total assets) and maturity structure (long-term debt over total debt) of the firms in our sample. We begin by estimating the following leverage model:

$$
(\mathrm{LTD} / \mathrm{TA})_{\mathrm{j}, \mathrm{i}, \mathrm{t}}=\alpha_{1}+\beta 1_{1} \mathrm{CRED}_{\mathrm{i}, \mathrm{t}}+\beta 1_{2} \operatorname{Control}_{\mathrm{j}, \mathrm{i}, \mathrm{t}}+\varepsilon 1
$$

where the dependent variable of long-term debt over total assets is indexed on firm $j$ in country $i$ in year $t$. CRED is a vector of variables based on the creditor rights score from LLSV (1996), enumerated in the Appendix. It is entered in various forms, either dummies for values (e.g., CRED-1 is a dummy variable that takes the value of "1" for all observations where the CRED score is equal to " 1 ", etc.), or dummies for the various components of the score (CRED-A, etc.). The vector of controls includes firm-level and country-level variables. Our firm-level controls include: EFFTAX (effective tax rate measured by taxes/net income), TANG (tangibility of assets measured by fixed assets/total assets), ROA (net income/total assets), and LNTA (the natural log of total assets).

We also employ two additional firm-level controls not used often in the previous literature. The variable LISTED takes the value of " 1 " for firms that were traded on a public stock exchange. There may be important distinctions between listed and unlisted firms in terms of their ability to obtain debt and to access longerterm debt. Finally, we include a variable ASSETSPEC (following Acharaya, et al, 2004), or asset specificity, which is a dummy variable taking the value of " 1 " for mining, manufacturing, and transportation firms (two-digit SIC codes 10-14; 20-39; and 40-49, respectively). Definitions and sources for all variables are contained in the appendix.

\section{Debt Maturity}

Our second set of empirical specifications uses debt maturity as the dependent variable; we estimate the following model: 


$$
(\mathrm{LTD} / \mathrm{TD})_{\mathrm{j}, \mathrm{i}, \mathrm{t}}=\alpha_{1}+\beta 1_{1} \mathrm{CRED}_{\mathrm{i}, \mathrm{t}}+\beta 1_{2} \operatorname{Control}_{\mathrm{j}, \mathrm{i}, \mathrm{t}}+\varepsilon 1
$$

where the dependent variable is long-term debt as a potion of total debt and the vector of independent variables is as defined above.

\section{Legal Origin}

We examine the robustness of the findings from estimations of equations (1) and (2), above, to inclusion of three dummy variables indicating French, German, and Scandinavian legal origin (Common law legal systems thus constitute the reference category). We base our legal family categorizations on LLSV, 1996 (which were consistent with those of 1997 for the countries in our sample). ${ }^{44}$

\section{Creditor Rights Scores from 1996 and 1997}

The CRED variable has been used in a large number of studies. For this paper, we explored the variable in detail and attempt to examine its usefulness in terms of explaining the level of leverage of privately held and publicly traded firms in Western Europe. Our baseline models employ the creditor rights score and list of components contained in LLSV (1996), which was based on in-depth research into commercial codes and bankruptcy law in a large number of countries around the world that are cited in that paper. The variable takes the value of 0 to 4 , and is meant to be a first take or approximation of the level of creditor protection in the country. See Panel C of the Appendix for a list of these values by country and legal origin.

Curiously, the values of the CRED score changed in a subsequent publication (LLSV, 1997) although the source for it in the more recent paper was in fact the original 1996 study. ${ }^{45}$ In Panel C of the Appendix, we specify how the variable changed between the two studies. Only one country (the UK) had its CRED score increase from 1996 to 1997, but a large number of countries (Finland, France, Ireland, Italy, Portugal, Sweden, and Switzerland) had lower scores in the 1997

\footnotetext{
${ }^{44}$ Unlike some non-European countries (e.g., Taiwan), we did not confront the situation where the commercial code was based on one legal family, whereas the bankruptcy code was based on another (Djankeov, et al, 2008).

45 The variable definition is presented on p. 49 of NBER working paper 5661 (LLSV, 1996), with values listed on p. 50.These scores constitute our baseline CRED variable, with components CREDA - CREDD.The "creditor rights" scores listed on p. 24 of NBER working paper 5879 on p. 24 are those we define as CRED97.
} 
publication. We looked closely for an explanation of this in the 1997 publication, as well as a Journal of Economic Literature (La Porta, et al, 2008) article that served to consolidate the various arguments related to legal origin, but could not find a reason as to why the scores were reduced in the 1997 vis-à-vis the 1996 study. Therefore, we employ the creditor rights score from the original 1996 paper, but supplement that analysis by using robustness tests on the 1997 creditor rights variable. We name the latter CRED-97 to distinguish it from our baseline CRED variable (and its derivative vectors of dummy variables) from the 1996 study.

We examine creditor rights in two different ways. First, based on previous analysis (LLSV), we use the CRED score as a proxy for the overall level of creditor protection in the country. Because in a regression context it is unclear that a movement from, e.g., 1 to 2 is equivalent to a movement from 3 to 4 , we break the variable down into a series of dummies. Thus, the dummy variable CRED-1 takes the value of " 1 " for all observations from countries with a CRED value of " 1 ". The dummy variable CRED-2 takes the value of " 1 " for all observations from countries with a creditor rights score of " 2 ".

Because there is likely also information contained in the various components of the score, in further tests we examine the disaggregated issues that were used to compile the score. The four categories are: (A) restrictions on reorganization, (B) no automatic stay that would prevent the right of creditors to take possession of property once petition for reorganization is recognized, (C) debtor does not retain possession of property pending resolution of reorganization, and (D) secured creditors are ranked first in the disposition of assets. For justifications as to why these legal characteristics support the interests of creditors (vis-à-vis debtors or other stakeholders), we refer the reader to the original paper (LLSV, 1996).

Based on the column headings in the Appendix (panel C), we construct a vector of four dummy variables taking the value of " 1 " for observations from countries in which that specific component of the creditor rights variable were extant in the law. Thus, observations from firms located in countries that had restrictions on reorganization (and hence would allow secured creditors to obtain their generally favored outcome of liquidation) would receive a value of "1" for CRED-A.

\section{Results}

Tables 2-6 present the basic results of our paper. In general, the models have very good fit, with Wald chi ${ }^{2}$ of very high magnitude. The $\mathrm{R}^{2}$ values, which range from $7.33 \%$ (model 5 , Table 4) to $26.14 \%$ (model 6, Table 6), are fairly

typical of previous work using similar data sets (e.g., Gianetti, 2003). The 
independent variables with large magnitudes and high levels of significance include asset tangibility as well as return on assets. Not surprisingly, firms with higher levels of tangible assets are in general and on average able to obtain a higher level of debt relative to total assets-we might expect this to be the case especially where better collateral laws and regulations make it easier for creditors to perfect claims on assets (Hall, 2012). It is also expected that firms with higher profitability will use less debt, a consistent finding throughout all of the specifications that included the return on assets variable. (ROA, along with the effective tax rate, was sometimes excluded so that observations from Ireland, the only other common law country besides the UK in the data set, could be included in some specifications.)

In terms of the major research questions posed at the beginning of the paper, we found relatively little evidence that the LLSV variable CRED (either from the 1996 or 1997 papers) has the expected relationship with leverage (or debt maturity). There was better evidence to suggest that legal origin (family) has a significant impact on leverage (and debt maturity), and this finding was confirmed, especially for French legal origin countries. We did find, however, that the legal efficiency measure (Djankov, et al, 2008) had better explanatory power than any of the versions of CRED we considered, or of legal family. Of the components of the CRED variable, we found that CRED-C, which measures whether creditors are to be paid first in the event of distress, was positively and significantly associated with leverage, as well as debt maturity. The other component parts of the CRED variable generally had either a negative or not significant relationship with leverage.

Some interesting findings regarding asset specificity emerged from the research. We found that, in general, firms with more specific assets (as defined above) employed less leverage on average, but had debt of longer maturity. This pattern was robust to consideration of the legal efficacy measure (although the relationship was not universal, as in Tables 5 and 6). The evidence is consistent with an interpretation that more specific assets discourage the use of debt, but that they were associated with a firm's ability to attract longer-term borrowing. We now turn to discussion of the results table by table.

\section{A. Baseline Models for Legal Origin}

In Table 2, we present regression coefficients for the baseline models

for legal origin. We see from columns 1 and 2 that, in line with the LLSV literature, firms located in German and especially French jurisdictions had less leverage and debt of lesser maturity, controlling for our independent variables. Scandinavian firms, ceteris paribus, had more leverage and longer-term debt. 
For these estimations, the reference category is common law, and the UK was the only such country in our dataset that had information on the income statement variables (return on assets and effective tax rate). To ensure that these basic results were not being driven by the fact that the common law category was exclusively occupied by UK firms, we omitted the income statement variables and re-estimated the baseline models in columns 3 and 4 . We found very similar results, with very similar magnitudes and z-statistics for the legal family dummies.

\section{B. Creditor Rights}

Table 3 presents results relating to creditor rights. Each of four specific creditor rights were detailed by LLSV (1996), and we use the sum of such rights indicated as the CRED variable (see the Appendix, Panel C). Although previous papers have simply entered the CRED variable into regression analysis, we do not feel this is the best way to proceed, because a one-unit change may not correspond to an equal impact on lending and collateral realities faced by banks and industrial firms. Thus, a movement on the CRED variable from 0 to 1 may not be equivalent to a movement from 3 to 4 . This suspicion is confirmed in later analysis, where we reveal that some of the components of the CRED score were more strongly associated with leverage vis-à-vis other components.

We get around this problem by generating a set of dummy variables taking the value of " 1 " for corresponding levels of the CRED score. Thus, for observations from a country with a CRED score of " 3 ", the variable CRED-3 will take a value of " 1 ", and " 0 " otherwise. Because there were no countries with a CRED score of zero (at least not until we encounter the CRED97 variable, see below), the reference category is CRED-1, or observations from countries with a CRED score of " 1 ". If the CRED score is effectively measuring the ability of creditors to perfect claims in the event of distress (which encourages them to lend to industrial firms), then the magnitude of the CRED dummy variables should in general and on average monotonically increase as we go from CRED-2 to CRED-3 to CRED-4.

Table 3 provides evidence on this. We do see that, in general, the coefficient for CRED-3 is higher than that for CRED-2, which is in line with expectations. The coefficient for CRED-4, however, has the opposite sign from expectations, and is highly significant across specifications, whether we include or omit legal family; whether we include or omit the income statement variables. This is 
not strong evidence in favor of the LLSV thesis that stronger creditor rights are associated with more robust corporate lending markets.

\section{Legal Family Results}

We continue our analysis by considering the argument of de Jong et al. (2011) that the firm-level determinants of leverage may in fact vary in different institutional settings. We find that, consistent with that perspective, the magnitude and significance level of several of our key independent covariates does depend on legal family. Thus, firms in common law and Scandinavian countries tended to have a very high coefficient for tangibility (around 20\% for specifications with LTD/TA as the dependent variable) whereas French and German family countries had a substantially lower value (of around 12\%). Many of the coefficients for the independent variables differ substantially by family, bolstering the perspective that legal origin matters.

\section{Components of the CRED Score}

It is important to realize that the CRED score is merely a sum of four different factors along which legal systems differ. Even if the battery of dummies created from the CRED variable do not have an important impact on leverage, it is possible that some of the component scores may affect the portion of debt in a firm's capital structure. Thus, consideration of the disaggregated elements of the score, and their impact on leverage and debt maturity, may be worthwhile.

Table 5 presents results from just such an exercise, with Panel A devoted to the four components (CRED-A through CRED-D) entered singly whereas in Panel B they are entered jointly. The first part of the table indicates, perhaps surprisingly, that many of the components of the CRED score are not in and of themselves associated with positive and significant impact on leverage. (Note that in Table 5, all regressions use LTD/TA as the dependent variable; we do not report results for LTD/TD for ease of presentation.) Whether omitting (columns 14) or including (columns 5-8) legal family dummy variables, we find that the only component of the CRED variable to have a consistently positive and significant coefficient is CRED-C, which relates to whether secured creditors are paid first (in the U.S., this is known as the absolute priority rule). We could imagine that this is one of the key aspects of credit markets, because if a lender is not first in line for any proceeds related to the liquidation of a distressed firm's assets, it may retard the 
development of lending facilities, leading to lower levels of debt relative to equity on balance sheets. Although an intuitive argument could be made for the other three components of the CRED score, they seem not to matter, or indeed to be associated with negative impact on leverage. This finding is robust to either entering the components singly (Panel A) or jointly (Panel B).

\section{E. Matched Sample Results}

A growing new area of research compares and contrasts financial performance of listed vis-à-vis unlisted companies. One of the advantages of using a large dataset including both types of firms is that we can examine the importance for leverage of having equity that is traded on a public exchange. Tables 2,3 , and 5 indicate consistently negative (and significant) coefficients for the listed dummy in terms of leverage, but positive (and significant) coefficients for debt maturity. The coefficients for this variable, however, vary based on legal family as shown in Table 4. Perhaps the results for the pooled data only reflect different composition of the underlying distribution of listed vis-à-vis unlisted firms in the different legal families. ${ }^{46}$

We investigate this issue further by constructing a set of matched unlisted companies for each listed firm in the data set. For each firm-year observation of a listed company, we found unlisted firms with identical year, country, and SIC code. We then selected an unlisted firm with slightly larger total assets, and another unlisted firm with slightly less total assets. For 2,725 firm-year observations of listed companies, we found a matched set of 5,414 unlisted firms. Such matched unlisted companies were much larger than the typical unlisted firm in the dataset. (The mean value of $\log$ total assets for the non-matched unlisted firms was 9.583; the value of $\log$ total assets for matched unlisted firms was 10.955; the $p$-value for difference in means is 0.000 and the nonparametric test for difference of medians also had a $p$ value of 0.000 .)

Table 6 provides evidence concerning whether the basic findings from previous results are robust to the matching procedure. The table indicates that the tangibility coefficient is still highly significant and positive, and the previous results for return on assets and size are robust to the matching procedure. Listed firms, relative to their unlisted matches, generally had less leverage. This is consistent with

${ }^{46}$ Indeed, it is been argued by LLSV, as well as a vast literature contrasting bank-based vis-à-vis market-based financial systems, that the prevalence of robust equity markets (as opposed to banking sectors) is related to the ability of firms to raise external finance for innovative (e.g., risky) projects. 
the argument made at the outset of the paper that corporate governance mechanisms may be at play in that unlisted firms (with presumably less dispersed ownership) were more likely to finance assets with debt, which can serve as a disciplining device. The finding is robust to whether we control for the CRED variable's level (in columns 34) or whether we control for the various components of the CRED score (in columns 5-6). The matched results did not show a significant impact of listed status concerning debt maturity. Consistent with earlier results, we found a positive and significant relationship between CRED-C and both leverage and debt maturity.

\section{Robustness and Interpretation of Results}

We employ three additional tests to determine the robustness of our results. First, we examine the efficiency of distress procedures in countries from various legal traditions with different types of creditor protections (Djankov, et al, 2008). The score developed by that paper is meant to measure the level of social utility that accompanies the "typical" scenario for resolving a distressed firm which is otherwise healthy as a going concern. Legal systems that allow for either a quick reorganization or liquidation receive higher scores, whereas countries where the bankruptcy process drags on for a long period, is very costly, or where social value is destroyed, received a lower score. Do the various findings we have developed so far stand up to inclusion of this variable? Second, we consider the alternative specification of the CRED variable that was released in the LLSV (1997) paper. Third, we examine whether the results so far are robust to inclusion of SIC fixed effects; the industry composition of firms in our sample varies somewhat by country and by legal family. We examine each set of robustness tests in turn.

\section{A. Social Efficiency of Bankruptcy Procedures}

Following Djankov, et al. (2008), we included a country-level estimate of the efficiency of "typical" bankruptcy procedures. This efficiency rating was based on survey responses by legal experts to likely resolution of a hypothetical, distressed, privately held firm. The measure incorporates the amount of value that would be recovered in the case, which was purposefully designed to test whether the legal system in question would either (1) retain the value of the firm, or (2) allow an otherwise profitable going concern to be liquidated. The study considered not only the cost of resolution, but the likely outcome in the form of foreclosure, liquidation, or reorganization. Because the measure of efficiency provides more information than 
dummy variables such as legal family, creditor rights, or CRED components, we consider it in our analysis of leverage (and debt maturity). Our supposition is that if creditors have confidence that the legal system will deliver value to them in the event of distress, they may be more likely to make a loan in the first place. This should affect the ability of firms to attract external finance in the form of debt, and hence affect capital structure.

Table 7 provides results of various estimations from previous results, but this time including the legal efficiency score. In every specification, the score has a positive and highly significant coefficient, with very stable magnitude for both leverage and debt maturity estimations. This indicates it is capturing something important about credit markets in the countries in our dataset.

Are the previous findings using various measures of creditor rights and legal family robust to inclusion of the efficiency variable? The legal family results are very different: all three legal family dummies now exhibit generally positive and significant coefficients (for both leverage and debt maturity). The legal family dummies include a lot of information about many different aspects of how commercial and bankruptcy codes operate, distilled into a single dummy variable. Conversely, the efficiency score is a composite based on the likelihood of various resolution scenarios specific to a privately-held firm. In this light, it is not surprising that the efficiency score captures better information about the functioning of credit markets in a cross-national perspective. The high z-scores (especially for columns 14) and consistent coefficient reinforce this interpretation.

Another interesting finding coming out of Table 7 is that, as shown previously, the CRED-C variable is positive and highly significant, both for leverage and debt maturity. Indeed, when the CRED components are considered in columns 5 and 6 , the level of significance of the efficiency variable declines substantially, with $\mathrm{z}$-scores now in the range of 11-14 as opposed to 50-64 as before.

\section{B. Difference in CRED scores between LLSV (1996) and LLSV (1997)}

As we noted above, the CRED scores released in LLSV (1997) were different from those of the original publication that detailed the components of CRED and then summed them to form the original scores. Because we were unsure as to why certain scores were changed from the 1996 to the 1997 papers, and because we were focused on examining the individual four components of the original score, we decided to use the CRED scores from 1996 for the bulk of the results for our paper. 
Nevertheless, the CRED scores were changed by LLSV for a reason, perhaps because of some errors in coding the 1996 data, or due to differences in interpretation of which scores reflected actual legal realities in the countries listed. In this section, we examine whether the basic findings are robust to consideration of the 1997 CRED scores. As before, rather than enter the CRED variable into a regression context, we use it to generate a number of dummy variables, with the reference category being CRED-4, the score for the United Kingdom.

The results using CRED-97 scores are indicated in Table 8. If the CRED-97 variable accurately reflected the importance of creditor rights for external debt financing of unlisted (and some listed) firms, we would expect a negative coefficient of the highest magnitude for CRED-0, and somewhat lower magnitudes decreasing to the lowest for CRED-3, indicating that relative to CRED-4, CRED-3 was closest in terms of providing protection to creditors in the event of firm distress.

We find that, as with the 1996 CRED scores, the expectation of monotonically progressive magnitude of coefficients as we move along values of the CRED score is not fulfilled. Indeed, we see that, for many specifications, the magnitude of the CRED97-3 is similar to that of CRED97-0. There is no consistent monotonic relationship, even between CRED97-1 and CRED97-2. We therefore conclude that the re-stated values of the CRED score in 1997 do not provide a superior measure of creditor protection than the 1996 paper.

\section{Industry Fixed Effects}

The analysis of listed firms in many nations by Fan, Titman, and Twite (2012) employs industry-level fixed effects. Are our results robust to such treatment? Table 9 indicates that, by country (Panel A) and by legal family (Panel B), there is some variation in the prevalence of different industry groups, such that, for example, almost twenty per cent of Portuguese firms are in SIC category 1, whereas only four per cent of Swiss firms are in that category. Similarly, about thirteen per cent of Common law family observations come from firms in the first SIC category, yet only nine per cent of Scandinavian firms do. For this reason, it makes sense to examine whether the major findings of this paper are robust to industry level fixed effects.

Table 9 (Panel C) presents summary findings, based on re-estimation of the models in Tables 2-8 but employing industry level (three-digit SIC codes) fixed effects specifications. Because asset specification is merely an artifact of industry 
code, that variable drops out of the analysis. We found that the majority of the key findings hold, even considering industry-level fixed effects.

\section{Note on Interpretation of "Good" Institutions}

This paper has focused on the ability of firms to obtain external finance, specifically debt finance. Although we have occasionally referred to the amount of leverage, we have throughout considered only the level of long-term debt relative to either the level of assets, or to the level of total debt. There has been a large literature related to whether access to external finance is facilitated by a wellfunctioning banking sector (e.g., Beck, et al, 2004) or by robust equity markets. ${ }^{47}$ It should be noted, however, that our study does not examine access to all forms of external finance, but specifically to debt finance. Therefore, one should not necessarily draw the conclusion from our work that, e.g., Scandinavia has a "good" system (vis-à-vis common law countries) because its dummy variable has generally positive coefficients. For example, it might be the case that Scandinavian firms face incentives to obtain high levels of debt finance because equity markets (related to low levels of legal protection for small shareholders) do not function as well as they do in common law countries. Similarly, a generally negative sign is not an inherent critique of French and German legal systems, because it might be the case that their equity markets are superior in some ways to common law (or Scandinavian countries); there is little evidence to support this supposition, however. Further research is warranted into the causal effects of institutional arrangements, and whether capital constrained firms (including small, privately held ones) are able to access external finance of various sorts to allow for expansion of successful projects in different institutional settings.

\section{Conclusion}

${ }^{47}$ Fan, Titman, and Twite (2012) argue that, "Specifically, the fact that institutions influence how firms are financed may provide an indirect channel through which a country's institutions affect economic growth. For example, there is reason to believe that if firms can raise more of their capital with equity and long-term debt, they will be better able to make longer-term investments, which may better promote economic growth. This suggeststhat an analysis of the relation between investment horizons and institutional structure offers an interesting avenue for future research." 
In this paper, we exploited the natural institutional variation of Western Europe to examine leverage and debt maturity. Unlike in most previous studies on leverage, however, we considered not only companies that are listed on public equity exchanges, but a large number of non-listed companies (NLCs) as well. We focused on firms in Western Europe, where the historical legacy of legal origin has not been diluted or adapted due to transplantation to another continent or to a wholly different social and historical tradition.

One of our key findings is that the widely-cited LLSV $(1996,1997)$ creditor rights measure CRED is not ideal for aspects of investor protection that affect leverage. We did not find that higher CRED scores, using either the version released in 1996 or the one from 1997, had the expected relationship (monotonic increase as creditor rights improve) with either leverage or debt maturity. One component of the CRED score was consistently and positively associated with leverage: whether secured creditors are paid first in the event of distress.

By supplementing the typical analysis of publicly traded companies with a very large sample of privately held firms, we were also able to consider whether status as a listed company affects leverage decisions. Using a matched sample of otherwise similar privately held companies, we find that listed firms have less debt, consistent with a corporate governance interpretation that presumably more dispersed publicly traded firms are more likely to avoid the disciplining device of leverage. The findings are robust to use of industry-level fixed effects. 


\section{R E F E R E N C E S}

Acharaya, V.; Sundaram, R.; and Kose, J. (2004).On the Capital Structure Implications of Bankruptcy Codes, London Business School Working Paper.

. (2008). Cross-Country Variations in Capital Structure and the Role of Bankruptcy Codes. New York University working paper.

Aggarwal, R. and Jamdee, S. (2003). Determinants of Capital Structure: Evidence from the G-7 Countries. Kent State University working paper.

Asker, John; Joan Farre-Mensa and Alexander Ljungqvist, (2011). Comparing the Investment Behaviour of Public and Private Firms, New York University working paper.

Beck, T. and R. Levine (2002). Industry growth and capital allocation: does having a market- or bank-based system matter? Journal of Financial Economics 64, 14780 .

Beck, T., Demirgüç-Kunt, A. and Maksimovic, V. (2002). Funding growth in bank based and market-based financial systems: Evidence from firm level data, Journal of Financial Economics, 65, 337-63.

- (2004). Bank competition and access to finance: International Evidence Journal of Money, Credit and Banking, 36, 627-48.

Beck, T., Demirgüç-Kunt, A. and Levine, R. (2003). Law and Finance: Why Does Legal Origin Matter? Journal of Comparative Economics, 31, 653-75. 
Booth, L; Aivazian, V., Demirgüç-Kunt, A., and Maksimovic, V., (2001). Capital Structures in Developing Countries Journal of Finance ,56, 87-130.

Deloitte and Touche (2000). IAS Plus Accounting Standards available at http://www.iasplus.com/dttpubs/ce2000.pdf.

Demirgüç-Kunt, A. and V. Maksimovic (1998).Law, finance, and firm growth.Journal of Finance, 53 , 2107-37.

. (1999). Institutions, financial markets, and firm debt maturity. Journal of Financial Economics ,54, 295-336.

. (2002). Funding growth systems in bank-based and market-based financial systems: evidence from firm-level data. Journal of Financial Economics, 65, 33763.

Fan, J.; Titman, S.; and Twite, G. (2012).International Comparison of Capital Structure and Debt Maturity Choices.Journal of Financial and Quantitative Analysis.

Frank, M. Goyal, V. (2005). Tradeoff and Pecking Order Theories of Debt in B.E. Eckbo (ed.), Handbook of Corporate Finance; Empirical Corporate Finance, (NorthHolland, Handbooks in Finance Series), Ch. 7.

Giannetti, Mariassunta, (2003). Do Better Institutions Mitigate Agency Problems? Evidence from Corporate Finance Choices, Journal of Financial and Quantitative Analysis, Vol. 38, No.1. 
Hall, Thomas (2011). "The Collateral Channel: Evidence on Leverage and Asset Tangibility." Journal of Corporate Finance.

Hall, Thomas and Frederick Jörgenson (2008). Legal Rights Matter: Evidence from Panel Data on Creditor Protection and Debt International Finance Review. Volume 9.

Klapper, L., Sarria-Allende, V. and Sulla, V. (2002).Small and Medium-Sized Enterprise Financing, in Eastern Europe, World Bank Working Paper.

La Porta, R., Lopez-de-Silanes, F.; Shleifer, A.; and Vishny, R. (1996), Law and Finance, NBER working paper 5661.

- (1997). Legal Determinants of External Finance.The Journal of Finance ,52, p. $1131-1151$. . (1998). Law and Finance.Journal of Political Economy106, 1113-55.

La Porta, R., Lopez-de-Silanes, F.; Shleifer, A. (2008). The Economic Consequences of Legal Origin, Journal of Economic Literature, 46:2, 285-332.

Martel, Sandra and Natalia Reisel (2009). The Real Benefit of Being Public: Evidence From Public and Private Firms. University of Memphis working paper.

Schmuckler, S. and Vesperoni, E. (2000). Firms' financing choices in bank-based and market-based economies World Bank working paper. 
Wald, J. (1999). How Firm Characteristics Affect Capital Structure: An International Comparison, The Journal of Financial Research, 22 , 161-188. 


\section{Appendix: Variables Employed}

\section{Panel A: Dependent Variables}

\begin{tabular}{|l|l|l|}
\hline Variable & Description & Source \\
\hline LTD/TA* & Long-Term Debt/Total Assets & Amadeus data base \\
\hline LTD/TD* & Long-Term Debt/Total Debt & Amadeus data base \\
\hline
\end{tabular}

\section{Panel B: Independent Variables}

\begin{tabular}{|c|c|c|}
\hline Variable & Description & Source \\
\hline EFFTAX* & Effective Tax Rate: Taxes/(EBIT-Interest) & Amadeus data base \\
\hline TANG & Tangible Assets: Net Fixed Assets/Total Assets & Amadeus data base \\
\hline ROA* & Return on Assets (EBIT-interest-taxes)/Total Assets & Amadeus data base \\
\hline LNTA & Natural Log of Total Assets & Amadeus data base \\
\hline CRED97 & Creditor Rights & La Porta, et al, 1997 \\
\hline CRED96 & Creditor Rights (for components A-D, see Panel C below) & La Porta, et al, 1996 \\
\hline LISTED & Dummy taking value of " 1 " for publicly-traded firms & Amadeus data base \\
\hline ASSETSPEC & $\begin{array}{l}\text { Dummy variable taking value of "1" for firms with highly-specific } \\
\text { assets (SIC categories 10-14, 20-39, and 40-49 including mining, } \\
\text { manufacturing, and transportation) }\end{array}$ & $\begin{array}{l}\text { Author calculations based on } \\
\text { Amadeus data base SIC } \\
\text { categorization }\end{array}$ \\
\hline Common & Dummy variable taking value of " 1 " for Ireland and UK & La Porta, et al, 1997 \\
\hline
\end{tabular}




\begin{tabular}{|l|l|l|}
\hline French & $\begin{array}{l}\text { Dummy variable taking value of "1" for France, Greece, Italy, } \\
\text { Portugal, and Spain }\end{array}$ & La Porta, et al, 1997 \\
\hline German & $\begin{array}{l}\text { Dummy variable taking value of "1" for Austria, Germany, and } \\
\text { Switzerland }\end{array}$ & La Porta, et al, 1997 \\
\hline Scandinavian & $\begin{array}{l}\text { Dummy variable taking value of "1" for Finland, Iceland, and } \\
\text { Sweden }\end{array}$ & La Porta, et al, 1997 \\
\hline Efficiency & $\begin{array}{l}\text { Effectiveness of "typical" bankruptcy procedures, measured as the } \\
\text { portion of value retained from a simple distressed case (survey of } \\
\text { experts) }\end{array}$ & Djankov, et al, 2008 \\
\hline
\end{tabular}

Panel C: Specifics on Creditor Rights and Legal Family Variables

\begin{tabular}{|c|c|c|c|c|c|c|c|c|}
\hline \multirow[b]{2}{*}{$\begin{array}{l}\text { Legal } \\
\text { Family }\end{array}$} & \multirow[b]{2}{*}{ Country } & \multirow[b]{2}{*}{$\begin{array}{c}\text { CRED } \\
97- \\
\text { CRED } \\
96\end{array}$} & \multirow[b]{2}{*}{$\begin{array}{c}\text { CRED97 } \\
\text { Creditor } \\
\text { Rights } \\
\text { Score } \\
\text { (LLSV, } \\
\text { 1997) }\end{array}$} & \multicolumn{5}{|c|}{ Components of Creditor Rights Score (LLSV, 1996) } \\
\hline & & & & $\begin{array}{c}\text { CRED96 } \\
=\text { Sum of } \\
\text { creditor } \\
\text { rights } \\
\text { A-D } \\
(1996)\end{array}$ & $\begin{array}{c}\text { A. } \\
\text { Reorgan- } \\
\text { ization } \\
\text { restrictions }\end{array}$ & $\begin{array}{c}\text { B. } \\
\text { Automat } \\
\text {-ic stay } \\
\text { on } \\
\text { assets }\end{array}$ & $\begin{array}{c}\text { C. } \\
\text { Secured } \\
\text { creditors } \\
\text { paid first }\end{array}$ & $\begin{array}{c}\text { D. } \\
\text { Mgt. does } \\
\text { not stay } \\
\text { in } \\
\text { reorgan- } \\
\text { ization }\end{array}$ \\
\hline \multirow{2}{*}{ Common } & UK & 2 & 4 & 2 & 1 & 0 & 1 & 0 \\
\hline & Ireland & -2 & 1 & 3 & 0 & 1 & 1 & 1 \\
\hline \multirow{4}{*}{ French } & France & -2 & 0 & 2 & 0 & 1 & 0 & 1 \\
\hline & Greece & 0 & 1 & 1 & 0 & 1 & 0 & 0 \\
\hline & Italy & -2 & 2 & 4 & 1 & 1 & 1 & 1 \\
\hline & Portugal & -2 & 1 & 3 & 0 & 1 & 1 & 1 \\
\hline
\end{tabular}




\begin{tabular}{|l|l|c|c|c|c|c|c|c|}
\hline & Spain & 0 & 2 & 2 & 0 & 0 & 1 & 1 \\
\hline \multirow{5}{*}{ German } & Austria & 0 & 3 & 3 & 1 & 0 & 1 & 1 \\
\cline { 2 - 9 } & Germany & 0 & 3 & 3 & 1 & 0 & 1 & 1 \\
\cline { 2 - 9 } & Switzerland & -2 & 1 & 3 & 0 & 1 & 1 \\
\hline \multirow{5}{*}{ Scand. } & Finland & -2 & 1 & 3 & 0 & 1 & 1 & 1 \\
\cline { 2 - 9 } & Iceland & $\mathrm{n} / \mathrm{a}$ & $\mathrm{n} / \mathrm{a}$ & $\mathrm{n} / \mathrm{a}$ & $\mathrm{n} / \mathrm{a}$ & $\mathrm{n} / \mathrm{a}$ & $\mathrm{n} / \mathrm{a}$ & $\mathrm{n} / \mathrm{a}$ \\
\cline { 2 - 9 }
\end{tabular}

*Windsorized as described in text (Frank and Goyal, 2005). 
Table 1: Data Description

(Following SIC-code narrowing, truncation of firm-years with negative book equity, and windsorization of outliers)

Panel A: Firm-Year Observations by Year and Legal Family

\begin{tabular}{|l|c|c|c|c|c|}
\hline Year & Common & French & German & Scandinavian & Total \\
\hline $\mathbf{1 9 9 5}$ & 9,993 & 1,588 & 181 & 15 & $\mathbf{1 1 , 7 7 7}$ \\
\hline $\mathbf{1 9 9 6}$ & 9,785 & 6,383 & 729 & 63 & $\mathbf{1 6 , 9 6 0}$ \\
\hline $\mathbf{1 9 9 7}$ & 8,348 & 24,976 & 1,067 & 2,483 & $\mathbf{3 6 , 8 7 4}$ \\
\hline $\mathbf{1 9 9 8}$ & 7,876 & 26,440 & 1,354 & 3,187 & $\mathbf{3 8 , 8 5 7}$ \\
\hline $\mathbf{1 9 9 9}$ & 7,583 & 28,268 & 1,613 & 3,506 & $\mathbf{4 0 , 9 7 0}$ \\
\hline $\mathbf{2 0 0 0}$ & 7,293 & 28,345 & 1,282 & 3,649 & $\mathbf{4 0 , 5 6 9}$ \\
\hline $\mathbf{2 0 0 1}$ & 7,448 & 23,549 & 262 & 3,676 & $\mathbf{3 4 , 9 3 5}$ \\
\hline Total & $\mathbf{5 8 , 3 2 6}$ & $\mathbf{1 3 9 , 5 4 9}$ & $\mathbf{6 , 4 8 8}$ & $\mathbf{1 6 , 5 7 9}$ & $\mathbf{2 2 0 , 9 4 2}$ \\
\hline
\end{tabular}

Panel B: Observations and Average Values of Dependent Variables 


\begin{tabular}{|c|c|c|c|c|}
\hline \multirow{2}{*}{ Country } & \multicolumn{2}{|c|}{$\begin{array}{c}\text { Long-Term Debt/ } \\
\text { Total Assets }\end{array}$} & \multicolumn{2}{|c|}{$\begin{array}{c}\text { Long-Term Debt/ } \\
\text { Total Debt }\end{array}$} \\
\hline & \# Obs. & Mean & \# Obs. & Mean \\
\hline Austria & 1,562 & 0.023 & 1,562 & 0.042 \\
\hline Finland & 4,460 & 0.132 & 4,460 & 0.218 \\
\hline France & 55,913 & 0.018 & 55,911 & 0.027 \\
\hline Germany & 4,604 & 0.060 & 4,602 & 0.111 \\
\hline Greece & 6,000 & 0.041 & 6,000 & 0.065 \\
\hline Iceland & 219 & 0.270 & 219 & 0.425 \\
\hline Ireland & 1,061 & 0.117 & 1,061 & 0.179 \\
\hline Italy & 34,991 & 0.006 & 34,988 & 0.010 \\
\hline Portugal & 1,922 & 0.131 & 1,922 & 0.190 \\
\hline Spain & 40,723 & 0.087 & 40,712 & 0.126 \\
\hline Sweden & 11,900 & 0.127 & 11,898 & 0.186 \\
\hline Switzerland & 322 & 0.185 & 322 & 0.311 \\
\hline UK & 27,820 & 0.107 & 27,811 & 0.159 \\
\hline
\end{tabular}


Panel C: Observations by Legal Family and Creditor Rights Score

\begin{tabular}{|c|c|c|c|c|c|}
\hline & & Credito & s Score & & \\
\hline Family & 1 & 2 & 3 & 4 & Total \\
\hline Common & 2,135 & 0 & 0 & 56,191 & 58,326 \\
\hline French & 68,835 & 75,714 & 0 & 0 & 139,549 \\
\hline German & 322 & 0 & 6,166 & 0 & 6,488 \\
\hline Scandinavian & 4,460 & 11,900 & 0 & 0 & 16,360 \\
\hline Total & 70,752 & 87,614 & 6,166 & 56,191 & 220,723 \\
\hline
\end{tabular}




\section{Table 2: Baseline Models}

The table reports coefficients (with z-statistics in parentheses) for estimations using general least squares. The dependent variables are either leverage (long-term debt over total assets) or maturity (long-term debt over total dabt). EffTax is the effective tax rate, defined as tax payments over net income; Tang is asset tangibility defined as fixed assets over total assets; return on assets $(\mathrm{ROA})$ is defined as net income over total assets. The variable LnTA is the natural log of total assets; AssetSpec refers to the specificity of assets and is a dummy variable taking the value of " 1 " for the mining, transportation, and manufacturing firms. Listed is a dummy variable taking the value of "1" for all firms that are listed on stock markets. The various CRED variables reflect dummies based on LLSV (1996) as indicated in the appendix.

\begin{tabular}{|c|c|c|c|c|}
\hline & (1) & (2) & (3) & (4) \\
\hline $\begin{array}{l}\text { Dependent } \\
\text { Variable }\end{array}$ & LTD/TA & LTD/TD & LTD/TA & LTD/TD \\
\hline Constant & $\begin{array}{c}0.032^{* * *} \\
10.03\end{array}$ & $\begin{array}{c}0.036^{* * *} \\
(8.27)\end{array}$ & $\begin{array}{c}0.020^{* * *} \\
(6.15)\end{array}$ & $\begin{array}{c}0.022^{* * *} \\
(5.14)\end{array}$ \\
\hline EffTax & $\begin{array}{l}-0.0003 \\
(-1.53)^{\dagger}\end{array}$ & $\begin{array}{l}-0.000 \\
(-0.87)\end{array}$ & -- & -- \\
\hline Tang & $\begin{array}{c}0.141^{* * *} \\
(86.23)\end{array}$ & $\begin{array}{c}0.222^{* * *} \\
(99.94)\end{array}$ & $\begin{array}{c}0.146^{* * *} \\
(89.90)\end{array}$ & $\begin{array}{l}0.225^{* * *} \\
(101.94)\end{array}$ \\
\hline ROA & $\begin{array}{c}-0.086^{* * *} \\
(-27.62)\end{array}$ & $\begin{array}{c}-0.078^{* * *} \\
(-18.01)\end{array}$ & -- & -- \\
\hline LnTA & $\begin{array}{c}0.003^{* * *} \\
11.86\end{array}$ & $\begin{array}{c}0.005^{* * *} \\
(12.30)\end{array}$ & $\begin{array}{c}0.004^{* * *} \\
(14.20)\end{array}$ & $\begin{array}{c}0.006^{* * *} \\
(14.82)\end{array}$ \\
\hline
\end{tabular}




\begin{tabular}{|c|c|c|c|c|}
\hline AssetSpec & $\begin{array}{c}-0.005^{* * *} \\
(-4.73)\end{array}$ & $\begin{array}{l}0.002 \\
(1.32)\end{array}$ & $\begin{array}{c}-0.006 * * * \\
(-5.22)\end{array}$ & $\begin{array}{l}0.002 \\
(1.37)\end{array}$ \\
\hline Listed & $\begin{array}{c}-0.007 * * * \\
-2.34\end{array}$ & $\begin{array}{c}0.024^{* * *} \\
(6.00)\end{array}$ & $\begin{array}{c}-0.009 * * * \\
(-2.86)\end{array}$ & $\begin{array}{c}0.021^{* * *} \\
(5.24)\end{array}$ \\
\hline French & $\begin{array}{c}-0.056^{* * *} \\
(-39.93)\end{array}$ & $\begin{array}{c}-0.078^{* * *} \\
(-41.69)\end{array}$ & $\begin{array}{c}-0.053 * * * \\
(-39.05)\end{array}$ & $\begin{array}{c}-0.076^{* * *} \\
(-41.92)\end{array}$ \\
\hline German & $\begin{array}{c}-0.065^{* * *} \\
(-24.83)\end{array}$ & $\begin{array}{c}-0.077 * * * \\
(-22.21)\end{array}$ & $\begin{array}{c}-0.062^{* * *} \\
(-23.75)\end{array}$ & $\begin{array}{c}-0.077 * * * \\
(-21.90)\end{array}$ \\
\hline Scandinavian & $\begin{array}{c}0.023^{* * *} \\
(11.48)\end{array}$ & $\begin{array}{c}0.042^{* * *} \\
(15.94)\end{array}$ & $\begin{array}{c}0.024^{* * *} \\
(11.97)\end{array}$ & $\begin{array}{c}0.043^{* * *} \\
(16.11)\end{array}$ \\
\hline Overall $\mathbf{R}^{2}$ & $16.22 \%$ & $20.55 \%$ & $15.44 \%$ & $20.02 \%$ \\
\hline Observations & 186,717 & 186,696 & 191,497 & 191,465 \\
\hline Firms & 46,535 & 46,532 & 47,421 & 47,416 \\
\hline Wald $\mathrm{chi}^{2}$ & $14,781 * * *$ & $18,906^{* * *}$ & $13,977 * * *$ & $18,468^{* * *}$ \\
\hline
\end{tabular}

$\dagger, *, * *$, and $* * *$ indicate significance at the $15 \%, 10 \%, 5 \%$, and $1 \%$ levels, respectively 


\section{Table 3: Creditor Rights and Legal Origin}

The table reports coefficients (with z-statistics in parentheses) for estimations using general least squares. The dependent variables are either leverage (long-term debt over total assets) or maturity (long-term debt over total dabt). EffTax is the effective tax rate, defined as tax payments over net income; Tang is asset tangibility defined as fixed assets over total assets; return on assets (ROA) is defined as net income over total assets. The variable LnTA is the natural log of total assets; AssetSpec refers to the specificity of assets and is a dummy variable taking the value of " 1 " for the mining, transportation, and manufacturing firms. Listed is a dummy variable taking the value of " 1 " for all firms that are listed on stock markets. The various CRED variables reflect dummies based on LLSV (1996) as indicated in the appendix.

\begin{tabular}{|c|c|c|c|c|c|c|}
\hline & (1) & (2) & (3) & (4) & (5) & (6) \\
\hline $\begin{array}{l}\text { Dependent } \\
\text { Variable }\end{array}$ & LTD / TA & LTD / TD & LTD / TA & LTD / TD & LTD / TA & LTD / TD \\
\hline Constant & $\begin{array}{c}0.022^{* * *} \\
(5.18)\end{array}$ & $\begin{array}{c}0.021^{* * * *} \\
(3.69)\end{array}$ & $\begin{array}{l}0.007 * \\
(1.67)\end{array}$ & $\begin{array}{l}0.004 \\
(0.70)\end{array}$ & $\begin{array}{c}-0.036 * * * \\
(-9.30)\end{array}$ & $\begin{array}{c}-0.058^{* * *} \\
(-11.38)\end{array}$ \\
\hline EffTax & $\begin{array}{l}-0.000 \\
(-0.60)\end{array}$ & $\begin{array}{l}0.000 \\
(0.17)\end{array}$ & -- & -- & $\begin{array}{c}-0.0004^{* *} \\
(-1.97)\end{array}$ & $\begin{array}{l}-0.000 \\
(-1.42)\end{array}$ \\
\hline Tang & $\begin{array}{c}0.137^{* * *} \\
(84.35)\end{array}$ & $\begin{array}{c}0.217^{* * *} * \\
(97.95)\end{array}$ & $\begin{array}{c}0.143^{* * *} \\
(88.30)\end{array}$ & $\begin{array}{l}0.221 * * * \\
(100.25)\end{array}$ & $\begin{array}{c}0.146^{* * *} \\
(88.71)\end{array}$ & $\begin{array}{c}0.230^{* * *} \\
(102.22\end{array}$ \\
\hline ROA & $\begin{array}{c}-0.093 * * * \\
(-29.61)\end{array}$ & $\begin{array}{c}-0.087 * * * \\
(-20.26)\end{array}$ & -- & -- & $\begin{array}{c}-0.081 * * * \\
(-25.71)\end{array}$ & $\begin{array}{c}-0.069 * * * \\
(-15.95)\end{array}$ \\
\hline LnTA & $\begin{array}{c}0.004^{* * *} \\
(14.48)\end{array}$ & $\begin{array}{c}0.006^{* * *} \\
(15.11)\end{array}$ & $\begin{array}{c}0.005^{* * *} \\
(16.71)\end{array}$ & $\begin{array}{c}0.007^{* * *} \\
(17.61)\end{array}$ & $\begin{array}{c}0.005^{* * *} \\
(17.65)\end{array}$ & $\begin{array}{c}0.007^{* * *} \\
(18.00)\end{array}$ \\
\hline AssetSpec & $\begin{array}{c}-0.005^{* * *} \\
(-4.21)\end{array}$ & $\begin{array}{l}0.003^{*} \\
(1.91)\end{array}$ & $\begin{array}{c}-0.005^{* * *} \\
(-4.81)\end{array}$ & $\begin{array}{l}0.003^{*} \\
(1.81)\end{array}$ & $\begin{array}{c}-0.007^{* * *} \\
(-6.35)\end{array}$ & $\begin{array}{l}-0.001 \\
(-0.66)\end{array}$ \\
\hline Listed & $\begin{array}{c}-0.015^{* * *} \\
(-4.99)\end{array}$ & $\begin{array}{c}0.012^{* * *} \\
(3.313)\end{array}$ & $\begin{array}{c}-0.016^{* * *} \\
(-5.29)\end{array}$ & $\begin{array}{c}0.010^{* * *} \\
(2.57)\end{array}$ & $\begin{array}{c}-0.009 * * * \\
(-2.87)\end{array}$ & $\begin{array}{c}0.021 * * * \\
(5.08)\end{array}$ \\
\hline
\end{tabular}




\begin{tabular}{|c|c|c|c|c|c|c|}
\hline CRED-2 & $\begin{array}{l}0.004 \\
(1.41)\end{array}$ & $\begin{array}{l}0.006 \dagger \\
(1.62)\end{array}$ & $\begin{array}{c}0.006^{* *} \\
(2.01)\end{array}$ & $\begin{array}{c}0.008^{* *} \\
(2.05)\end{array}$ & $\begin{array}{c}0.015^{* * *} \\
(5.10)\end{array}$ & $\begin{array}{c}0.021^{* * *} \\
(5.48)\end{array}$ \\
\hline CRED-3 & $\begin{array}{c}0.015^{* * *} \\
(4.13)\end{array}$ & $\begin{array}{c}0.033^{* * *} \\
(6.69)\end{array}$ & $\begin{array}{c}0.017^{* * *} \\
(4.56)\end{array}$ & $\begin{array}{c}0.033^{* * *} \\
(6.77)\end{array}$ & $\begin{array}{c}0.029 * * * \\
(8.72)\end{array}$ & $\begin{array}{c}0.055^{* * *} \\
(12.50)\end{array}$ \\
\hline CRED-4 & $\begin{array}{c}-0.035^{* * *} \\
(-11.70)\end{array}$ & $\begin{array}{c}-0.047 * * * \\
(-12.13)\end{array}$ & $\begin{array}{c}-0.031 \text { *** } \\
(-10.21)\end{array}$ & $\begin{array}{c}-0.044^{* * *} \\
(-11.07)\end{array}$ & $\begin{array}{c}-0.008^{* * *} \\
(-2.62)\end{array}$ & $\begin{array}{c}-0.008^{* *} \\
(-2.06)\end{array}$ \\
\hline French & $\begin{array}{c}-0.047 * * * \\
-32.35\end{array}$ & $\begin{array}{c}-0.065^{* * *} \\
(-34.01)\end{array}$ & $\begin{array}{c}-0.044 * * * \\
(-31.30)\end{array}$ & $\begin{array}{c}-0.063 * * * \\
(-33.66)\end{array}$ & -- & -- \\
\hline German & $\begin{array}{c}-0.076^{* * *} \\
(-20.44)\end{array}$ & $\begin{array}{c}-0.104 * * * \\
(-21.06)\end{array}$ & $\begin{array}{c}-0.072 * * * \\
(-20.38)\end{array}$ & $\begin{array}{c}-0.100^{* * *} \\
(-21.24)\end{array}$ & -- & -- \\
\hline Scandinavian & $\begin{array}{c}0.046^{* * *} \\
(19.05)\end{array}$ & $\begin{array}{c}0.071 \text { *** } \\
(22.18)\end{array}$ & $\begin{array}{c}0.046^{* * *} \\
(19.48)\end{array}$ & $\begin{array}{c}0.072 * * * \\
(22.91)\end{array}$ & -- & -- \\
\hline Overall $\mathbf{R}^{2}$ & $17.50 \%$ & $21.89 \%$ & $16.50 \%$ & $21.19 \%$ & $11.49 \%$ & $15.49 \%$ \\
\hline Obs. & 186,498 & 186,477 & 191,278 & 191,246 & 186,498 & 186,477 \\
\hline Firms & 46,453 & 46,450 & 47,339 & 47,334 & 46,453 & 46,450 \\
\hline Wald chi ${ }^{2}$ & $15,848^{* * *}$ & $20,223 * * *$ & $14,872^{* * *}$ & $19,631^{* * *}$ & $11,137 * * *$ & $14,358 * * *$ \\
\hline
\end{tabular}

${ }^{\dagger}, *, * *$, and $* * *$ indicate significance at the $15 \%, 10 \%, 5 \%$, and $1 \%$ levels, respectively 
Table 4: Legal Family

The table reports coefficients (with z-statistics in parentheses) for estimations using general least squares. The dependent variables are either leverage (long-term debt over total assets) or maturity (long-term debt over total dabt). EffTax is the effective tax rate, defined as tax payments over net income; Tang is asset tangibility defined as fixed assets over total assets; return on assets (ROA) is defined as net income over total assets. The variable LnTA is the natural log of total assets; AssetSpec refers to the specificity of assets and is a dummy variable taking the value of "1" for the

mining, transportation, and manufacturing firms. Listed is a dummy variable taking the value of "1" for all firms that are listed on stock markets. The various CRED variables reflect dummies based on LLSV (1996) as indicated in the appendix.

\begin{tabular}{|c|c|c|c|c|c|c|c|c|c|c|}
\hline & (1) & (2) & (3) & (4) & (5) & (6) & (7) & (8) & (9) & (10) \\
\hline & \multicolumn{4}{|c|}{ Common Law } & \multicolumn{2}{|c|}{ French } & \multicolumn{2}{|c|}{ German } & \multicolumn{2}{|c|}{ Scandinavian } \\
\hline $\begin{array}{l}\text { Dependent } \\
\text { Variable: }\end{array}$ & $\begin{array}{c}\mathrm{LTD} / \mathrm{T} \\
\mathbf{A}\end{array}$ & $\begin{array}{c}\mathrm{LTD} / \mathrm{T} \\
\mathrm{D}\end{array}$ & $\begin{array}{c}\mathrm{LTD} / \mathrm{T} \\
\mathbf{A}\end{array}$ & $\begin{array}{c}\mathrm{LTD} / \mathrm{T} \\
\mathrm{D}\end{array}$ & $\begin{array}{c}\mathrm{LTD} / \mathrm{T} \\
\mathbf{A}\end{array}$ & $\begin{array}{c}\mathrm{LTD} / \mathrm{T} \\
\mathrm{D}\end{array}$ & $\begin{array}{c}\mathrm{LTD} / \mathrm{T} \\
\mathrm{A}\end{array}$ & $\begin{array}{c}\mathrm{LTD} / \mathrm{T} \\
\mathrm{D}\end{array}$ & $\begin{array}{c}\mathrm{LTD} / \mathrm{T} \\
\mathbf{A}\end{array}$ & $\begin{array}{c}\text { LTD } / T \\
\text { D }\end{array}$ \\
\hline Constant & $\begin{array}{c}-0.116^{* * *} \\
(-12.23)\end{array}$ & $\begin{array}{c}-0.179 * * * \\
(-14.65)\end{array}$ & $\begin{array}{c}-0.089 * * * \\
(-8.87)\end{array}$ & $\begin{array}{c}-0.153^{* * *} \\
(-11.86)\end{array}$ & $\begin{array}{l}0.000 \\
(0.17)\end{array}$ & $\begin{array}{l}0.000 \\
(0.00)\end{array}$ & $\begin{array}{c}-0.065 * * * \\
(-4.73)\end{array}$ & $\begin{array}{c}-0.155^{* * *} \\
(-7.02)\end{array}$ & $\begin{array}{c}0.149^{* * *} \\
(11.77)\end{array}$ & $\begin{array}{c}0.185^{* * *} \\
(10.68)\end{array}$ \\
\hline EffTax & -- & -- & $\begin{array}{l}0.000 \\
(0.25)\end{array}$ & $\begin{array}{l}0.000 \\
(0.20)\end{array}$ & $\begin{array}{c}-0.0004 * \\
(-1.89)\end{array}$ & $\begin{array}{c}-0.0005^{*} \\
(-1.71)\end{array}$ & $\begin{array}{l}0.001 \\
(0.62)\end{array}$ & $\begin{array}{l}0.003^{\dagger} \\
(1.47)\end{array}$ & $\begin{array}{l}-0.002^{\dagger} \\
(-1.55)\end{array}$ & $\begin{array}{l}-0.001 \\
(-0.48)\end{array}$ \\
\hline
\end{tabular}




\begin{tabular}{|c|c|c|c|c|c|c|c|c|c|c|}
\hline Tang & $\begin{array}{c}0.200^{* * *} \\
(41.40)\end{array}$ & $\begin{array}{c}0.309 * * * \\
(48.63)\end{array}$ & $\begin{array}{c}0.205^{* * *} \\
(39.28)\end{array}$ & $\begin{array}{c}0.333^{* * *} \\
(49.03)\end{array}$ & $\begin{array}{c}0.118^{* * *} \\
(70.52)\end{array}$ & $\begin{array}{c}0.184 * * * \\
(80.68)\end{array}$ & $\begin{array}{c}0.119 * * * \\
(14.76)\end{array}$ & $\begin{array}{c}0.190 * * * \\
(14.61)\end{array}$ & $\begin{array}{c}0.206^{* * *} \\
(28.84)\end{array}$ & $\begin{array}{c}0.317 * * * \\
(32.34)\end{array}$ \\
\hline ROA & -- & -- & $\begin{array}{c}-0.123^{* * *} \\
(-12.96)\end{array}$ & $\begin{array}{c}-0.117^{* * *} \\
(9.22)\end{array}$ & $\begin{array}{l}-0.05^{* * *} \\
(-14.24)\end{array}$ & $\begin{array}{c}-0.035^{* * *} \\
(-7.34)\end{array}$ & $\begin{array}{c}-0.046^{* * *} \\
(-2.71)\end{array}$ & $\begin{array}{l}-0.018 \\
(-0.63)\end{array}$ & $\begin{array}{c}-0.184^{* * *} \\
(17.30)\end{array}$ & $\begin{array}{c}-0.186^{* * *} \\
(-12.70)\end{array}$ \\
\hline LnTA & $\begin{array}{c}0.015^{* * *} \\
(16.61)\end{array}$ & $\begin{array}{c}0.022 * * * \\
(18.63)\end{array}$ & $\begin{array}{c}0.013 * * * \\
(13.31)\end{array}$ & $\begin{array}{c}0.019 \text { *** } \\
(15.38)\end{array}$ & $\begin{array}{c}0.001 * * * \\
(4.35)\end{array}$ & $\begin{array}{c}0.001 * * * \\
(3.10)\end{array}$ & $\begin{array}{c}0.007 * * * \\
(5.09)\end{array}$ & $\begin{array}{c}0.015^{* * *} \\
(3.10)\end{array}$ & $\begin{array}{c}-0.007^{* * *} \\
(-5.95)\end{array}$ & $\begin{array}{c}-0.008^{* * *} \\
(-4.53)\end{array}$ \\
\hline AssetSpec & $\begin{array}{l}0.005 \\
(1.36)\end{array}$ & $\begin{array}{c}0.019 * * * \\
(4.09)\end{array}$ & $\begin{array}{l}0.006 \\
(1.43)\end{array}$ & $\begin{array}{c}0.015^{* * *} \\
(3.19)\end{array}$ & $\begin{array}{c}-0.004^{* * *} \\
(-3.50)\end{array}$ & $\begin{array}{l}0.002 \\
(1.10)\end{array}$ & $\begin{array}{l}0.005 \\
(1.17)\end{array}$ & $\begin{array}{c}0.032^{* * *} \\
(4.42)\end{array}$ & $\begin{array}{c}-0.038^{* * *} \\
(-7.19)\end{array}$ & $\begin{array}{c}-0.028^{* * *} \\
(-4.01)\end{array}$ \\
\hline Listed & $\begin{array}{c}-0.052^{* * *} \\
(-7.23)\end{array}$ & $\begin{array}{c}-0.031 * * * \\
(-3.32)\end{array}$ & $\begin{array}{c}-0.050^{* * *} \\
(-6.96)\end{array}$ & $\begin{array}{c}-0.026^{* * *} \\
(-2.97)\end{array}$ & $\begin{array}{l}-0.003 \\
(-0.89)\end{array}$ & $\begin{array}{c}0.013^{* * *} \\
(2.59)\end{array}$ & $\begin{array}{c}0.017^{* *} \\
(2.35)\end{array}$ & $\begin{array}{c}0.063 * * * \\
(5.37)\end{array}$ & $\begin{array}{l}0.036^{* *} \\
(2.51)\end{array}$ & $\begin{array}{c}0.089 * * * \\
(4.59)\end{array}$ \\
\hline Overall $\mathbf{R}^{2}$ & $14.86 \%$ & $21.38 \%$ & $17.30 \%$ & $24.23 \%$ & $7.33 \%$ & $9.91 \%$ & $12.68 \%$ & $16.83 \%$ & $12.97 \%$ & $14.08 \%$ \\
\hline Obs. & 28,881 & 28,869 & 24,525 & 24,524 & 139,336 & 139,320 & 6,288 & 6,284 & 16,570 & 16,568 \\
\hline
\end{tabular}




\begin{tabular}{|c|c|c|c|c|c|c|c|c|c|c|}
\hline Firms & 7,785 & 7,783 & 6,937 & 6,937 & 33,160 & 33,157 & 1,944 & 1,944 & 4,513 & 4,513 \\
\hline Wald chi ${ }^{2}$ & $2,353^{* * *}$ & $3,329 * * *$ & $2,403 * * *$ & $3,497 * * *$ & $5,771^{* * * *}$ & $7,361 * * *$ & $388 * * *$ & $542^{* * *}$ & $1,269 * * *$ & $1,371^{* * *}$ \\
\hline
\end{tabular}

$\dagger, *, * *$, and ${ }^{* * *}$ indicate significance at the $15 \%, 10 \%, 5 \%$, and $1 \%$ levels, respectively 
Table 5: Pooled Estimations of CRED Components and Legal Origin

\section{PANEL A: Components Entered Singly}

The table reports coefficients (with z-statistics in parentheses) for estimations using general least squares. The dependent variable is leverage (long-term debt over total assets). EffTax is the effective tax rate, defined as tax payments over net income; Tang is asset tangibility defined as fixed assets over total assets; return on assets (ROA) is defined as net income over total assets. The variable LnTA is the natural log of total assets; AssetSpec refers to the specificity of assets and is a dummy variable taking the value of " 1 " for the mining, transportation, and manufacturing firms. Listed is a dummy variable taking the value of " 1 " for all firms that are listed on stock markets. The various CRED variables reflect dummies based on LLSV (1996) as indicated in the appendix.

\begin{tabular}{|c|c|c|c|c|c|c|c|c|}
\hline & (1) & (2) & (3) & (4) & (5) & (6) & (7) & (8) \\
\hline Constant & $\begin{array}{c}-0.027^{* * *} \\
(-9.90)\end{array}$ & $\begin{array}{c}0.009^{* * *} \\
(3.33)\end{array}$ & $\begin{array}{c}-0.049 * * * \\
(-17.84)\end{array}$ & $\begin{array}{c}0.020^{* * *} \\
(6.39)\end{array}$ & $\begin{array}{c}0.066^{* * *} \\
(19.74)\end{array}$ & $\begin{array}{c}0.018^{* * *} \\
(5.59)\end{array}$ & $\begin{array}{l}0.005 \\
(1.36)\end{array}$ & $\begin{array}{c}0.033^{* * *} \\
(10.15)\end{array}$ \\
\hline EffTax & $\begin{array}{c}-0.001 * * \\
(-2.44)\end{array}$ & $\begin{array}{c}-0.0004^{* *} \\
(-2.00)\end{array}$ & $\begin{array}{c}-0.001 \text { *** } \\
(-2.87)\end{array}$ & $\begin{array}{c}-0.0004^{* *} \\
(-2.14)\end{array}$ & $\begin{array}{l}-0.000 \\
(-0.53)\end{array}$ & $\begin{array}{l}-0.000 \\
(-1.01)\end{array}$ & $\begin{array}{c}-0.0004^{*} \\
(-1.97)\end{array}$ & $\begin{array}{c}-0.003 \dagger \\
(1.51)\end{array}$ \\
\hline Tang & $\begin{array}{c}0.148^{* * *} \\
(89.96)\end{array}$ & $\begin{array}{c}0.142^{* * *} \\
(86.95)\end{array}$ & $\begin{array}{c}0.144 * * * \\
(87.72)\end{array}$ & $\begin{array}{c}0.146^{* * *} \\
(88.63)\end{array}$ & $\begin{array}{c}0.146^{* * *} \\
(84.38)\end{array}$ & $\begin{array}{c}0.135^{* * *} \\
(83.30)\end{array}$ & $\begin{array}{c}0.139 * * * \\
(85.27)\end{array}$ & $\begin{array}{c}0.140^{* * *} \\
(85.79)\end{array}$ \\
\hline ROA & $\begin{array}{c}-0.078^{* * *} \\
(-24.85)\end{array}$ & $\begin{array}{c}-0.082^{* * *} \\
(-26.07)\end{array}$ & $\begin{array}{c}-0.078^{* * *} \\
(-24.75)\end{array}$ & $\begin{array}{c}-0.080^{* * *} \\
(-25.53)\end{array}$ & $\begin{array}{c}-0.093^{* * *} \\
(-29.74)\end{array}$ & $\begin{array}{c}-0.092 * * * \\
(-26.68)\end{array}$ & $\begin{array}{c}-0.085^{* * *} \\
(-27.07)\end{array}$ & $\begin{array}{c}-0.086^{* * *} \\
(-27.58)\end{array}$ \\
\hline Ln'TA & $\begin{array}{c}0.005^{* * *} \\
(17.64)\end{array}$ & $\begin{array}{c}0.004^{* * *} \\
(15.72)\end{array}$ & $\begin{array}{c}0.004^{* * *} \\
(15.44)\end{array}$ & $\begin{array}{c}0.004^{* * *} \\
(12.84)\end{array}$ & $\begin{array}{c}0.004^{* * *} \\
(14.74)\end{array}$ & $\begin{array}{c}0.005^{* * *} \\
(17.47)\end{array}$ & $\begin{array}{c}0.003^{* * *} \\
(12.05)\end{array}$ & $\begin{array}{c}0.003^{* * *} \\
(11.91)\end{array}$ \\
\hline AssetSpec & $\begin{array}{c}-0.008^{* * *} \\
(-7.08)\end{array}$ & $\begin{array}{c}-0.007 * * * \\
(-6.14)\end{array}$ & $\begin{array}{c}-0.008^{* * *} \\
(-7.14)\end{array}$ & $\begin{array}{c}-0.008^{* * *} \\
(-6.81)\end{array}$ & $\begin{array}{c}-0.005^{* * *} \\
(-4.18)\end{array}$ & $\begin{array}{c}-0.005 * * * \\
(-4.65)\end{array}$ & $\begin{array}{c}-0.006^{* * *} \\
(-5.44)\end{array}$ & $\begin{array}{c}-0.006^{* * *} \\
(-5.10)\end{array}$ \\
\hline Listed & $\begin{array}{l}-0.005^{*} \\
(-1.72)\end{array}$ & $\begin{array}{c}-0.010^{* * *} \\
(-3.32)\end{array}$ & $\begin{array}{l}-0.003 \\
(-1.02)\end{array}$ & $\begin{array}{c}-0.014^{* * *} \\
(-4.67)\end{array}$ & $\begin{array}{c}-0.016^{* * *} \\
(-5.34)\end{array}$ & $\begin{array}{c}-0.008^{* * *} \\
(-2.70)\end{array}$ & $\begin{array}{c}-0.007 * * \\
(-2.37)\end{array}$ & $\begin{array}{c}-0.011 * * * \\
(-3.73)\end{array}$ \\
\hline CRED-A & $\begin{array}{l}0.001 \\
(0.58)\end{array}$ & -- & -- & -- & $\begin{array}{c}-0.041 * * * \\
(-33.84)\end{array}$ & -- & -- & -- \\
\hline
\end{tabular}




\begin{tabular}{|c|c|c|c|c|c|c|c|c|}
\hline CRED-B & -- & $\begin{array}{c}-0.047 * * * \\
(-47.45)\end{array}$ & -- & -- & -- & $\begin{array}{c}-0.063 * * * \\
(-52.94))\end{array}$ & -- & -- \\
\hline CRED-C & -- & -- & $\begin{array}{c}0.045^{* * *} \\
(42.91)\end{array}$ & -- & -- & -- & $\begin{array}{c}0.028 * * * \\
(25.07)\end{array}$ & -- \\
\hline CRED-D & -- & -- & -- & $\begin{array}{c}-0.039 * * * \\
(-29.87)\end{array}$ & -- & -- & -- & $\begin{array}{c}-0.005^{*} \\
(-1.78)\end{array}$ \\
\hline French & -- & -- & -- & -- & $\begin{array}{c}-0.087 * * * \\
(-52.50)\end{array}$ & $\begin{array}{c}-0.011 * * * \\
(-6.82)\end{array}$ & $\begin{array}{c}-0.044 * * * \\
(-29.89)\end{array}$ & $\begin{array}{c}-0.052^{* * *} \\
(-16.99)\end{array}$ \\
\hline German & -- & -- & -- & -- & $\begin{array}{c}-0.066^{* * *} \\
(-25.48)\end{array}$ & $\begin{array}{c}-0.060^{* * *} \\
(-23.62)\end{array}$ & $\begin{array}{c}-0.064 * * * \\
(-24.76)\end{array}$ & $\begin{array}{c}-0.060^{* * *} \\
(-15.56)\end{array}$ \\
\hline Scand. & -- & -- & -- & -- & $\begin{array}{c}0.010^{* * *} \\
(5.17)\end{array}$ & $\begin{array}{c}0.086 * * * \\
(37.13)\end{array}$ & $\begin{array}{c}0.021 * * * \\
(10.49)\end{array}$ & $\begin{array}{c}0.026^{* * *} \\
(7.46)\end{array}$ \\
\hline Obs. & \multicolumn{8}{|c|}{186,498} \\
\hline Firms & \multicolumn{8}{|c|}{46,453} \\
\hline Overall $\mathbf{R}^{2}$ & $10.64 \%$ & $14.52 \%$ & $13.49 \%$ & $11.83 \%$ & $17.59 \%$ & $20.39 \%$ & $16.88 \%$ & $15.97 \%$ \\
\hline Wald chi ${ }^{2}$ & $10,545^{* * *}$ & $13,092^{* * *}$ & $12,639 * * *$ & $11,566^{* * *}$ & $15,885^{* * *}$ & $17,880^{* * *}$ & $15,268^{* * *}$ & $14,507^{* * *}$ \\
\hline
\end{tabular}


Table 5: Pooled Estimations of CRED Components and Legal Origin

PANEL B: Components Entered Jointly

The table reports coefficients (with z-statistics in parentheses) for estimations using general least squares. The dependent variable is leverage (long-term debt over total assets). EffTax is the effective tax rate, defined as tax payments over net income; Tang is asset tangibility defined as fixed assets over total assets; return on assets (ROA) is defined as net income over total assets. The variable LnTA is the natural log of total assets; AssetSpec refers to the specificity of assets and is a dummy variable taking the value of " 1 " for the mining, transportation, and manufacturing firms. Listed is a dummy variable taking the value of "1" for all firms that are listed on stock markets. The various CRED variables reflect dummies based on LLSV (1996) as indicated in the appendix.

\begin{tabular}{|c|c|c|c|c|}
\hline & (1) & (2) & (3) & (4) \\
\hline Dependent Variable: & $\begin{array}{c}\text { LTD / } \\
\text { TA }\end{array}$ & $\begin{array}{c}\text { LTD / } \\
\text { TD }\end{array}$ & $\begin{array}{c}\text { LTD / } \\
\text { TA }\end{array}$ & $\begin{array}{c}\text { LTD / } \\
\text { TD }\end{array}$ \\
\hline Constant & $\begin{array}{c}-0.011 * * * \\
(-3.23)\end{array}$ & $\begin{array}{c}-0.031 * * * \\
(-7.03)\end{array}$ & $\begin{array}{c}0.028^{* * *} \\
(8.34)\end{array}$ & $\begin{array}{c}0.028^{* * *} \\
(6.21)\end{array}$ \\
\hline EffTax & $\begin{array}{c}-0.0004^{* *} \\
(-2.00)\end{array}$ & $\begin{array}{c}-0.0004 \dagger \\
-1.49\end{array}$ & $\begin{array}{l}-0.000 \\
(-0.64)\end{array}$ & $\begin{array}{l}0.000 \\
(0.15)\end{array}$ \\
\hline Tang & $\begin{array}{c}0.139^{* * *} \\
(85.44)\end{array}$ & $\begin{array}{c}0.220^{* * *} \\
(99.34)\end{array}$ & $\begin{array}{c}0.132^{* * *} \\
(82.55)\end{array}$ & $\begin{array}{c}0.210^{* * *} \\
(95.81)\end{array}$ \\
\hline ROA & $\begin{array}{c}-0.086^{* * *} \\
(-27.47)\end{array}$ & $\begin{array}{c}-0.076^{* * *} \\
(-17.65)\end{array}$ & $\begin{array}{c}-0.096^{* * *} \\
(-30.81)\end{array}$ & $\begin{array}{c}-0.092^{* * *} \\
(-21.51)\end{array}$ \\
\hline LnTA & $\begin{array}{c}0.005^{* * *} \\
(17.30)\end{array}$ & $\begin{array}{c}0.007^{* * *} \\
(18.52)\end{array}$ & $\begin{array}{c}0.005^{* * *} \\
(18.20)\end{array}$ & $\begin{array}{c}0.007^{* * *} \\
(19.35)\end{array}$ \\
\hline AssetSpec & $\begin{array}{c}-0.008 * * * \\
(-2.11)\end{array}$ & $\begin{array}{l}-0.002 \\
(-1.29)\end{array}$ & $\begin{array}{c}-0.005^{* * *} \\
(-18.20)\end{array}$ & $\begin{array}{l}0.002 \\
(1.40)\end{array}$ \\
\hline Listed & $\begin{array}{c}-0.013^{* * *} \\
(-4.36)\end{array}$ & $\begin{array}{c}-0.017^{* * *} \\
(-4.75)\end{array}$ & $\begin{array}{c}-0.014 * * * \\
(-4.75)\end{array}$ & $\begin{array}{c}0.013^{* * *} \\
(3.48)\end{array}$ \\
\hline (Reorganization & $-0.059 * * *$ & $-0.084 * * *$ & $-0.056^{* * *}$ & $-0.090 * * *$ \\
\hline
\end{tabular}




\begin{tabular}{|c|c|c|c|c|}
\hline restrictions) & $(-36.33)$ & $(-39.17)$ & $(-24.47)$ & $(-29.52)$ \\
\hline CRED-B (Automatic stay on assets) & $\begin{array}{c}0.010^{* * *} \\
(6.25)\end{array}$ & $\begin{array}{c}0.017 * * * \\
(8.15)\end{array}$ & $\begin{array}{c}-0.018^{* * *} \\
(-7.17)\end{array}$ & $\begin{array}{c}-0.015^{* * *} \\
(-4.40)\end{array}$ \\
\hline $\begin{array}{l}\text { CRED-C (Secured creditors paid } \\
\text { first) }\end{array}$ & $\begin{array}{c}0.080^{* * *} \\
(42.25)\end{array}$ & $\begin{array}{c}0.119 * * * \\
(47.02)\end{array}$ & $\begin{array}{c}0.045^{* * *} \\
(18.20)\end{array}$ & $\begin{array}{c}0.075 * * * \\
(22.92)\end{array}$ \\
\hline $\begin{array}{l}\text { CRED-D (Management does not } \\
\text { stay) }\end{array}$ & $\begin{array}{l}-0.058^{* * *} \\
(-33.74)\end{array}$ & $\begin{array}{l}-0.081 * * * \\
(-35.05)\end{array}$ & $\begin{array}{c}-0.024 * * * \\
(-8.48)\end{array}$ & $\begin{array}{c}-0.033^{* * *} \\
(-9.04)\end{array}$ \\
\hline French & -- & -- & $\begin{array}{l}-0.043^{* * *} \\
(-10.94)\end{array}$ & $\begin{array}{l}-0.070^{* * *} \\
(-13.47)\end{array}$ \\
\hline German & -- & -- & $\begin{array}{l}-0.040 * * * \\
(-10.63)\end{array}$ & $\begin{array}{c}-0.044 * * * \\
(-8.74)\end{array}$ \\
\hline Scandinavian & -- & -- & $\begin{array}{l}0.049 * * * \\
(10.68)\end{array}$ & $\begin{array}{l}0.065 * * * \\
(10.79)\end{array}$ \\
\hline Overall $\mathbf{R}^{2}$ & $16.86 \%$ & $20.91 \%$ & $21.13 \%$ & $25.75 \%$ \\
\hline Obs. & 186,498 & 186,477 & 186,498 & 186,477 \\
\hline Firms & 46,453 & 46.450 & 45,453 & 46.450 \\
\hline Wald chi ${ }^{2}$ & $15,446^{* * *}$ & $19,408^{* * *}$ & $18,794^{* * *}$ & $23,919 * * *$ \\
\hline
\end{tabular}


Table 6: Matched Sample Results

The table reports coefficients (with z-statistics in parentheses) for estimations using general least squares. The dependent variables are either leverage (long-term debt over total assets) or maturity (long-term debt over total dabt). EffTax is the effective tax rate, defined as tax payments over net income; Tang is asset tangibility defined as fixed assets over total assets; return on assets (ROA) is defined as net income over total assets. The variable LnTA is the natural log of total assets; AssetSpec refers to the specificity of assets and is a dummy variable taking the value of " 1 " for the mining, transportation, and manufacturing firms. Listed is a dummy variable taking the value of " 1 " for all firms that are listed on stock markets. The various CRED variables reflect dummies based on LLSV (1996) as indicated in the appendix. Observations are restricted only to listed firms with matched non-listed firms; matched observations have identical year, country, and SIC code with either slightly larger or slightly smaller size (measured as log total assets).

\begin{tabular}{|c|c|c|c|c|c|c|}
\hline & (1) & (2) & (3) & (4) & (5) & (6) \\
\hline $\begin{array}{l}\text { Dependent } \\
\text { Variable }\end{array}$ & LTD / TA & LTD / TD & LTD / TA & LTD / TD & LTD / TA & LTD / TD \\
\hline Constant & $\begin{array}{l}-0.006 \\
(-0.46)\end{array}$ & $\begin{array}{c}-0.056^{* * *} \\
(-2.95)\end{array}$ & $\begin{array}{l}0.003 \\
(0.21)\end{array}$ & $\begin{array}{l}-0.038^{*} \\
(-1.88)\end{array}$ & $\begin{array}{l}0.003 \\
(0.17)\end{array}$ & $\begin{array}{c}-0.043^{* *} \\
(-2.05)\end{array}$ \\
\hline EffTax & $\begin{array}{l}-0.000 \\
(-0.33)\end{array}$ & $\begin{array}{l}0.002 \\
(0.85)\end{array}$ & $\begin{array}{l}-0.000 \\
(-0.31)\end{array}$ & $\begin{array}{l}0.002 \\
(0.87)\end{array}$ & $\begin{array}{l}-0.001 \\
(-0.35)\end{array}$ & $\begin{array}{l}0.002 \\
0.83\end{array}$ \\
\hline Tang & $\begin{array}{c}0.157^{* * *} \\
(20.72)\end{array}$ & $\begin{array}{c}0.277^{* * *} \\
(26.18)\end{array}$ & $\begin{array}{c}0.152^{* * *} \\
(20.06)\end{array}$ & $\begin{array}{c}0.269^{* * *} \\
(25.41)\end{array}$ & $\begin{array}{c}0.144^{* * *} \\
(19.17)\end{array}$ & $\begin{array}{c}0.257^{* * *} \\
(24.48)\end{array}$ \\
\hline ROA & $\begin{array}{c}-0.088^{* * *} \\
(-5.28)\end{array}$ & $\begin{array}{c}-0.086^{* * *} \\
(-3.61)\end{array}$ & $\begin{array}{c}-0.096 * * * \\
(-5.78)\end{array}$ & $\begin{array}{c}-0.101 * * * \\
(-4.22)\end{array}$ & $\begin{array}{c}-0.101 * * * \\
(-6.12)\end{array}$ & $\begin{array}{c}-0.019^{* * *} \\
(-4.59)\end{array}$ \\
\hline LnTA & $\begin{array}{c}0.006^{* * *} \\
(5.04)\end{array}$ & $\begin{array}{c}0.011 * * * \\
(6.65)\end{array}$ & $\begin{array}{c}0.007^{* * *} \\
(5.64)\end{array}$ & $\begin{array}{c}0.012^{* * *} \\
(7.39)\end{array}$ & $\begin{array}{c}0.006^{* * *} \\
(5.33)\end{array}$ & $\begin{array}{c}0.012^{* * *} \\
(7.02)\end{array}$ \\
\hline AssetSpec & $\begin{array}{c}0.010^{* *} \\
(2.51)\end{array}$ & $\begin{array}{c}0.028^{* * *} \\
(4.92)\end{array}$ & $\begin{array}{c}0.008^{* *} \\
(1.99)\end{array}$ & $\begin{array}{c}0.024 * * * \\
(4.33)\end{array}$ & $\begin{array}{l}0.004 \\
(1.06)\end{array}$ & $\begin{array}{c}0.019 * * * \\
(3.37)\end{array}$ \\
\hline Listed & $\begin{array}{c}-0.020 * * * \\
(-4.30)\end{array}$ & $\begin{array}{l}-0.004 \\
(-0.58)\end{array}$ & $\begin{array}{c}-0.021 * * * \\
(-4.53)\end{array}$ & $\begin{array}{l}-0.005 \\
(-0.83)\end{array}$ & $\begin{array}{c}-0.021^{* * *} \\
(-4.47)\end{array}$ & $\begin{array}{l}-0.004 \\
(-0.70)\end{array}$ \\
\hline French & $\begin{array}{c}-0.054 * * * \\
(-12.28)\end{array}$ & $\begin{array}{c}-0.076^{* * *} \\
(-12.73)\end{array}$ & $\begin{array}{c}-0.055^{* * *} \\
(-11.64)\end{array}$ & $\begin{array}{c}-0.028^{* * *} \\
(-2.72)\end{array}$ & $\begin{array}{c}-0.029 * * \\
(-2.04)\end{array}$ & $\begin{array}{c}-0.043^{* *} \\
(-2.24)\end{array}$ \\
\hline
\end{tabular}




\begin{tabular}{|c|c|c|c|c|c|c|}
\hline German & $\begin{array}{c}-0.044 * * * \\
(-6.21)\end{array}$ & $\begin{array}{c}-0.047 * * * \\
(-4.83)\end{array}$ & $\begin{array}{c}-0.089 * * * \\
(-6.74)\end{array}$ & $\begin{array}{c}0.050 * * * \\
(2.91)\end{array}$ & $\begin{array}{l}-0.012 \\
(-1.14)\end{array}$ & $\begin{array}{l}0.006 \\
(0.43)\end{array}$ \\
\hline Scand. & $\begin{array}{c}-0.024 * * * \\
(-0.008)\end{array}$ & $\begin{array}{l}-0.015 \\
(-1.38)\end{array}$ & $\begin{array}{c}-0.026 * * \\
(-2.53)\end{array}$ & $\begin{array}{c}-0.062^{* * *} \\
(-4.38)\end{array}$ & $\begin{array}{l}-0.003 \\
(-0.17)\end{array}$ & $\begin{array}{l}0.010 \\
(0.41)\end{array}$ \\
\hline CRED-2 & -- & -- & $\begin{array}{c}-0.015^{* *} \\
(-2.07)\end{array}$ & $\begin{array}{c}-0.028^{* * *} \\
(-2.72)\end{array}$ & -- & -- \\
\hline CRED-3 & -- & -- & $\begin{array}{c}0.030 * * \\
(2.34)\end{array}$ & $\begin{array}{c}0.050^{* * *} \\
2.91\end{array}$ & -- & -- \\
\hline CRED-4 & -- & -- & $\begin{array}{c}-0.039 * * * \\
(-3.77)\end{array}$ & $\begin{array}{c}-0.062^{* * *} \\
(-4.38)\end{array}$ & -- & -- \\
\hline CRED-A & -- & -- & -- & -- & $\begin{array}{c}-0.078^{* * *} \\
(-7.95)\end{array}$ & $\begin{array}{c}-0.125^{* * *} \\
(-9.42)\end{array}$ \\
\hline CRED-B & -- & -- & -- & -- & $\begin{array}{l}-0.017 \dagger \\
(-1.47)\end{array}$ & $\begin{array}{l}-0.017 \\
(-1.09)\end{array}$ \\
\hline CRED-C & -- & -- & -- & -- & $\begin{array}{c}0.072^{* * *} \\
(6.97)\end{array}$ & $\begin{array}{c}0.118^{* * *} \\
(8.41)\end{array}$ \\
\hline CRED-D & -- & -- & -- & -- & $\begin{array}{c}-0.035 * * * \\
(-4.55)\end{array}$ & $\begin{array}{c}-0.056 * * * \\
(-5.50)\end{array}$ \\
\hline Overall $\mathbf{R}^{2}$ & $16.67 \%$ & $20.37 \%$ & $17.38 \%$ & $23.51 \%$ & $19.60 \%$ & $26.14 \%$ \\
\hline Obs. & 7,761 & 7,759 & 7,755 & 7,753 & 7,755 & 7,753 \\
\hline Firms & 4,481 & 4,479 & 4,475 & 4,473 & 4,475 & 4,473 \\
\hline
\end{tabular}




\begin{tabular}{|l|l|l|l|l|l|l|}
\hline Wald chi & \\
\hline & $1,009 * * *$ & $1,501 * * *$ & $1,061 * * *$ & $1,583 * * *$ & $1,217^{* * *}$ & $1,796^{* * *}$ \\
\hline
\end{tabular}

$\dagger, *, * *$, and $* * *$ indicate significance at the $15 \%, 10 \%, 5 \%$, and $1 \%$ levels, respectively

Table 7: Robustness to Legal Efficiency

The table reports coefficients (with z-statistics in parentheses) for estimations using general least squares. The dependent variables are either leverage (long-term debt over total assets) or maturity (long-term debt over total dabt). EffTax is the effective tax rate, defined as tax payments over net income; Tang is asset tangibility defined as fixed assets over total assets; return on assets (ROA) is defined as net income over total assets. The variable LnTA is the natural log of total assets; AssetSpec refers to the specificity of assets and is a dummy variable taking the value of " 1 " for the mining, transportation, and manufacturing firms. Listed is a dummy variable taking the value of " 1 " for all firms that are listed on stock markets. The various CRED variables are dummies based on LLSV (1996) as indicated in the appendix.

\begin{tabular}{|c|c|c|c|c|c|c|}
\hline & (1) & (2) & (3) & (4) & (5) & (6) \\
\hline Dependent Variable & LTD/ TA & LTD/ TD & LTD/ TA & LTD/ TD & LTD/ TA & LTD/ TD \\
\hline Constant & $\begin{array}{c}-0.186^{* * *} \\
(-38.50)\end{array}$ & $\begin{array}{c}-0.272^{* * *} \\
(-42.13)\end{array}$ & $\begin{array}{c}-0.170^{* * *} \\
(-30.11)\end{array}$ & $\begin{array}{c}-0.246 * * * \\
(-32.76)\end{array}$ & $\begin{array}{c}-0.168 * * * \\
(-12.08)\end{array}$ & $\begin{array}{c}-0.175^{* * *} \\
(-9.44)\end{array}$ \\
\hline EffTax & $\begin{array}{l}-0.000 \\
(-0.40)\end{array}$ & $\begin{array}{l}0.000 \\
(0.41)\end{array}$ & $\begin{array}{l}-0.000 \\
(-0.41)\end{array}$ & $\begin{array}{c}0.210^{* * *} \\
(95.70)\end{array}$ & $\begin{array}{c}0.132^{* * *} \\
(81.90)\end{array}$ & $\begin{array}{c}0.209 * * * \\
(95.60)\end{array}$ \\
\hline Tang & $\begin{array}{c}0.132^{* * *} \\
(82.15)\end{array}$ & $\begin{array}{c}0.210^{* * *} \\
(95.90)\end{array}$ & $\begin{array}{c}0.132^{* * *} \\
(82.01)\end{array}$ & $\begin{array}{c}0.210^{* * *} \\
(95.70)\end{array}$ & $\begin{array}{c}0.132^{* * *} \\
(81.90)\end{array}$ & $\begin{array}{c}0.209 * * * \\
(95.60)\end{array}$ \\
\hline ROA & $\begin{array}{c}-0.096^{* * *} \\
(-30.48)\end{array}$ & $\begin{array}{c}-0.092 * * * \\
(-21.41)\end{array}$ & $\begin{array}{c}-0.096^{* * *} \\
(-30.91)\end{array}$ & $\begin{array}{c}-0.093^{* * *} \\
(-21.57)\end{array}$ & $\begin{array}{c}-0.096^{* * *} \\
(-30.93)\end{array}$ & $\begin{array}{c}-0.093^{* * *} \\
(-21.60)\end{array}$ \\
\hline LnTA & $\begin{array}{c}0.005^{* * *} \\
(18.87)\end{array}$ & $\begin{array}{c}0.008^{* * *} \\
(20.07)\end{array}$ & $\begin{array}{c}0.005^{* * *} \\
(19.00)\end{array}$ & $\begin{array}{c}0.008^{* * *} \\
(20.07)\end{array}$ & $\begin{array}{c}0.005^{* * *} \\
(18.80)\end{array}$ & $\begin{array}{c}0.008^{* * *} \\
(19.811)\end{array}$ \\
\hline AssetSpec & $\begin{array}{c}-0.004 * * * \\
(-4.07)\end{array}$ & $\begin{array}{c}0.003^{* *} \\
(2.20)\end{array}$ & $\begin{array}{c}-0.005^{* * *} \\
(-4.54)\end{array}$ & $\begin{array}{l}0.002 * \\
(1.69)\end{array}$ & $\begin{array}{c}-0.005^{* * *} \\
(-4.58)\end{array}$ & $\begin{array}{l}0.002^{\dagger} \\
(1.59)\end{array}$ \\
\hline Listed & $\begin{array}{c}-0.010^{* * *} \\
(-3.42)\end{array}$ & $\begin{array}{c}0.193^{* * *} \\
(5.03)\end{array}$ & $\begin{array}{c}-0.012^{* * *} \\
(-4.18)\end{array}$ & $\begin{array}{c}0.016^{* * *} \\
(4.14)\end{array}$ & $\begin{array}{c}-0.013 * * * \\
(-4.41)\end{array}$ & $\begin{array}{c}0.014 * * * \\
(3.76)\end{array}$ \\
\hline Efficiency & $\begin{array}{c}0.002^{* * *} \\
(60.32)\end{array}$ & $\begin{array}{c}0.003^{* * *} \\
(63.92)\end{array}$ & $\begin{array}{c}0.002^{* * *} \\
(50.63)\end{array}$ & $\begin{array}{c}0.003 * * * \\
(53.04)\end{array}$ & $\begin{array}{c}0.002^{* * *} \\
(14.55)\end{array}$ & $\begin{array}{c}0.002^{* * *} \\
(11.32)\end{array}$ \\
\hline
\end{tabular}




\begin{tabular}{|c|c|c|c|c|c|c|}
\hline French & $\begin{array}{c}0.013^{* * *} \\
(7.45)\end{array}$ & $\begin{array}{c}0.019 * * * \\
(8.22)\end{array}$ & $\begin{array}{c}0.014^{* * *} \\
(7.31)\end{array}$ & $\begin{array}{c}0.018^{* * *} \\
(7.48)\end{array}$ & $\begin{array}{c}0.016^{* * *} \\
(2.78)\end{array}$ & $\begin{array}{l}-0.010 \\
-1.28\end{array}$ \\
\hline German & $\begin{array}{l}0.001 \\
(0.37)\end{array}$ & $\begin{array}{c}0.015^{* * *} \\
(4.14)\end{array}$ & $\begin{array}{c}-0.006 * \\
(-1.68)\end{array}$ & $\begin{array}{l}-0.008 \dagger \\
(-1.52)\end{array}$ & $\begin{array}{c}0.018^{* * *} \\
(3.23)\end{array}$ & $\begin{array}{c}0.016^{* *} \\
(2.23)\end{array}$ \\
\hline Scandinavian & $\begin{array}{c}0.033^{* * *} \\
(17.03)\end{array}$ & $\begin{array}{c}0.057^{* * *} \\
(21.98)\end{array}$ & $\begin{array}{c}0.027^{* * *} \\
(11.42)\end{array}$ & $\begin{array}{c}0.045^{* * *} \\
(14.31)\end{array}$ & $\begin{array}{c}0.038^{* * *} \\
(8.26)\end{array}$ & $\begin{array}{c}0.054^{* * *} \\
(8.83)\end{array}$ \\
\hline CRED-2 & -- & -- & $\begin{array}{c}-0.024 * * * \\
(-8.56)\end{array}$ & $\begin{array}{c}-0.033 * * * \\
(-8.83)\end{array}$ & -- & -- \\
\hline CRED-3 & -- & -- & $\begin{array}{c}-0.014 * * * \\
(-3.76)\end{array}$ & $\begin{array}{l}-0.007 \dagger \\
(-1.49)\end{array}$ & -- & -- \\
\hline CRED-4 & -- & -- & $\begin{array}{c}-0.019 * * * \\
(-6.64)\end{array}$ & $\begin{array}{c}-0.026^{* * *} \\
(-6.87)\end{array}$ & -- & -- \\
\hline CRED-A & -- & -- & -- & -- & $\begin{array}{c}-0.019 * * * \\
(-5.39)\end{array}$ & $\begin{array}{c}-0.051 * * * \\
(-11.14)\end{array}$ \\
\hline CRED-B & -- & -- & -- & -- & $\begin{array}{c}0.013^{* * *} \\
(3.96)\end{array}$ & $\begin{array}{c}0.017^{* * *} \\
(4.02)\end{array}$ \\
\hline CRED-C & -- & -- & -- & -- & $\begin{array}{c}0.022 * * * \\
(7.34)\end{array}$ & $\begin{array}{c}0.051^{* * *} \\
(13.07)\end{array}$ \\
\hline CRED-D & -- & -- & -- & -- & $\begin{array}{c}-0.024 * * * \\
(-8.68)\end{array}$ & $\begin{array}{c}-0.034 * * * \\
(-9.19)\end{array}$ \\
\hline Overall $\mathbf{R}^{2}$ & $21.21 \%$ & $25.61 \%$ & $21.31 \%$ & $25.73 \%$ & $21.36 \%$ & $25.87 \%$ \\
\hline
\end{tabular}




\begin{tabular}{|l|c|c|c|c|c|c|}
\hline Obs. & 186,498 & 186,477 & 186,498 & 186,477 & 186,498 & 186,477 \\
\hline Firms & 46,453 & 46,450 & 46,453 & 46,450 & 46,453 & 46,450 \\
\hline Wald chi ${ }^{2}$ & $18,908^{* * *}$ & $23,767^{* * *}$ & $19,021^{* * *}$ & $23,947^{* * *}$ & $19,075^{* * *}$ & $24,107^{* * *}$ \\
\hline
\end{tabular}

Table 8: Robustness to CRED97

The table reports coefficients (with z-statistics in parentheses) for estimations using general least squares. The dependent variables are either leverage (long-term debt over total assets) or maturity (long-term debt over total dabt). EffTax is the effective tax rate, defined as tax payments over net income; Tang is asset tangibility defined as fixed assets over total assets; return on assets (ROA) is defined as net income over total assets. The variable LnTA is the natural log of total assets; AssetSpec refers to the specificity of assets and is a dummy variable taking the value of " 1 " for the mining, transportation, and manufacturing firms. Listed is a dummy variable taking the value of " 1 " for all firms that are listed on stock markets. The various CRED97 variables reflect dummies based on LLSV (1997) as indicated in the appendix; note that in the rest of the paper, we use values from the 1996 LLSV paper. Columns 7 and 8 use only matched observations of listed firms based on year, country, SIC, and size (log of total assets).

\begin{tabular}{|c|c|c|c|c|c|c|c|c|}
\hline & (1) & (2) & (3) & (4) & (5) & (6) & (7) & (8) \\
\hline Obs. Used: & \multicolumn{2}{|c|}{ All but Ireland } & \multicolumn{4}{|c|}{ All (including Ireland) } & \multicolumn{2}{|c|}{ Matched Only } \\
\hline $\begin{array}{l}\text { Dependent } \\
\text { Variable: }\end{array}$ & $\begin{array}{c}\text { LTD / } \\
\text { TA }\end{array}$ & $\begin{array}{c}\text { LTD / } \\
\text { TD }\end{array}$ & $\begin{array}{c}\text { LTD / } \\
\text { TA }\end{array}$ & $\begin{array}{c}\text { LTD / } \\
\text { TD }\end{array}$ & $\begin{array}{c}\text { LTD / } \\
\text { TA }\end{array}$ & $\begin{array}{c}\text { LTD / } \\
\text { TD }\end{array}$ & $\begin{array}{c}\text { LTD / } \\
\text { TA }\end{array}$ & $\begin{array}{c}\text { LTD / } \\
\text { TD }\end{array}$ \\
\hline Constant & $\begin{array}{c}0.032^{* * *} \\
(9.77)\end{array}$ & $\begin{array}{c}0.035^{* * *} \\
(7.93)\end{array}$ & $\begin{array}{c}0.020^{* * *} \\
(6.14)\end{array}$ & $\begin{array}{c}0.022^{* * *} \\
(5.06)\end{array}$ & $\begin{array}{c}-0.185^{* * *} \\
(-36.40)\end{array}$ & $\begin{array}{c}-0.268^{* * *} \\
(-39.54)\end{array}$ & $\begin{array}{c}-0.239 * * * \\
(-8.94)\end{array}$ & $\begin{array}{c}-0.398^{* * *} \\
(-10.87)\end{array}$ \\
\hline EffTax & $\begin{array}{c}-0.001 * * \\
(-2.43)\end{array}$ & $\begin{array}{c}-0.001 * \\
(-1.90)\end{array}$ & -- & -- & -- & -- & -- & -- \\
\hline Tang & $\begin{array}{c}0.141 * * * \\
(86.58)\end{array}$ & $\begin{array}{c}0.224^{* * *} \\
(100.25)\end{array}$ & $\begin{array}{c}0.143^{* * *} \\
(88.59)\end{array}$ & $\begin{array}{l}0.221 * * * \\
(100.56)\end{array}$ & $\begin{array}{c}0.138^{* * *} \\
(85.97)\end{array}$ & $\begin{array}{l}0.213^{* *} \\
(98.04)\end{array}$ & $\begin{array}{c}0.153^{* * *} \\
(20.65)\end{array}$ & $\begin{array}{c}0.270^{* * *} \\
(26.13)\end{array}$ \\
\hline ROA & $\begin{array}{c}-0.082^{* * *} \\
(-26.10)\end{array}$ & $\begin{array}{c}-0.071 \text { *** } \\
(-16.34)\end{array}$ & -- & -- & -- & -- & -- & -- \\
\hline LnTA & $0.004 * * *$ & $0.005^{* * *}$ & $0.004^{* * *}$ & $0.006^{* * *}$ & $0.006^{* * *}$ & $0.009 * * *$ & $0.007 * * *$ & $0.013^{* * *}$ \\
\hline
\end{tabular}




\begin{tabular}{|c|c|c|c|c|c|c|c|c|}
\hline & (12.38) & (12.93) & (14.73) & $(15.47)$ & $(20.72)$ & (22.13) & (6.14) & (7.97) \\
\hline AssetSpec & $\begin{array}{c}-0.008^{* * *} \\
(-7.34)\end{array}$ & $\begin{array}{l}-0.002^{*} \\
(-1.67)\end{array}$ & $\begin{array}{c}-0.007 * * * \\
(-6.53)\end{array}$ & $\begin{array}{l}-0.000 \\
(-0.07)\end{array}$ & $\begin{array}{c}-0.005^{* * *} \\
(-5.02)\end{array}$ & $\begin{array}{l}0.002^{*} \\
(1.65)\end{array}$ & $\begin{array}{l}0.001 \\
(0.31)\end{array}$ & $\begin{array}{c}0.014 * * * \\
(2.62)\end{array}$ \\
\hline Listed & $\begin{array}{c}-0.014^{* * *} \\
(-4.62)\end{array}$ & $\begin{array}{c}0.013^{* * *} \\
(3.25)\end{array}$ & $\begin{array}{c}-0.015^{* * *} \\
(-4.90)\end{array}$ & $\begin{array}{c}0.011^{* * *} \\
(2.80)\end{array}$ & $\begin{array}{c}-0.014 * * * \\
(-4.86)\end{array}$ & $\begin{array}{c}0.012^{* * *} \\
(2.98)\end{array}$ & $\begin{array}{c}-0.020 * * * \\
(-4.325)\end{array}$ & $\begin{array}{l}-0.005 \\
(-0.79)\end{array}$ \\
\hline Efficiency & -- & -- & -- & -- & $\begin{array}{c}0.002^{* * *} \\
(51.56)\end{array}$ & $\begin{array}{c}0.003 * * * \\
(54.92)\end{array}$ & $\begin{array}{c}0.002^{* * *} \\
(9.32)\end{array}$ & $\begin{array}{c}0.003^{* * *} \\
(10.10)\end{array}$ \\
\hline CRED97-0 & $\begin{array}{c}-0.075^{* * *} \\
(-47.32)\end{array}$ & $\begin{array}{c}-0.105^{* * *} \\
(-49.85)\end{array}$ & $\begin{array}{c}-0.034 * * * \\
(-5.04)\end{array}$ & $\begin{array}{c}-0.051 * * * \\
(-5.66)\end{array}$ & $\begin{array}{l}-0.004 \\
(-0.56)\end{array}$ & $\begin{array}{l}-0.008 \\
(-0.92)\end{array}$ & $\begin{array}{l}0.002 \\
(0.08)\end{array}$ & $\begin{array}{l}0.029 \\
(0.79)\end{array}$ \\
\hline CRED97-1 & $\begin{array}{c}-0.007^{* * *} \\
(-3.44)\end{array}$ & $\begin{array}{l}-0.001 \\
(0.33)\end{array}$ & $\begin{array}{l}0.008 \\
(1.23)\end{array}$ & $\begin{array}{l}0.015^{*} \\
(1.76)\end{array}$ & $\begin{array}{c}0.014^{* *} \\
(2.20)\end{array}$ & $\begin{array}{c}0.023^{* * *} \\
(2.83)\end{array}$ & $\begin{array}{l}0.035 \\
(1.37)\end{array}$ & $\begin{array}{c}0.086^{* *} \\
(2.45)\end{array}$ \\
\hline CRED97-2 & $\begin{array}{c}-0.037 * * * \\
(-25.13)\end{array}$ & $\begin{array}{c}-0.050^{* * *} \\
(-25.49)\end{array}$ & $\begin{array}{l}-0.006 \\
(-0.82)\end{array}$ & $\begin{array}{l}-0.010 \\
(-1.13)\end{array}$ & $\begin{array}{l}0.002 \\
(0.35)\end{array}$ & $\begin{array}{l}0.001 \\
(0.12)\end{array}$ & $\begin{array}{l}0.019 \\
(0.70)\end{array}$ & $\begin{array}{l}0.054 \dagger \\
(1.48)\end{array}$ \\
\hline CRED97-3 & $\begin{array}{c}-0.068^{* * *} \\
(-25.52)\end{array}$ & $\begin{array}{c}-0.083^{* * *} \\
(-23.27)\end{array}$ & $\begin{array}{c}-0.110^{* * *} \\
(-8.06)\end{array}$ & $\begin{array}{c}-0.170^{* * *} \\
(-9.43)\end{array}$ & $\begin{array}{c}-0.107 * * * \\
(-8.05)\end{array}$ & $\begin{array}{c}-0.166^{* * *} \\
(-9.45)\end{array}$ & $\begin{array}{c}-0.084^{*} \\
(-1.71)\end{array}$ & $\begin{array}{l}-0.102^{\dagger} \\
(-1.54)\end{array}$ \\
\hline French & -- & -- & $\begin{array}{c}-0.038^{* * *} \\
(-5.72)\end{array}$ & $\begin{array}{c}-0.052^{* * *} \\
(-5.95)\end{array}$ & $\begin{array}{l}0.011 * \\
(1.73)\end{array}$ & $\begin{array}{c}0.017^{* *} \\
(1.98)\end{array}$ & $\begin{array}{l}0.017 \\
(0.64)\end{array}$ & $\begin{array}{l}-0.001 \\
(-0.01)\end{array}$ \\
\hline German & -- & -- & $\begin{array}{c}0.044^{* * *} \\
(3.29)\end{array}$ & $\begin{array}{c}0.088^{* * *} \\
(4.97)\end{array}$ & $\begin{array}{c}0.102^{* * *} \\
(7.82)\end{array}$ & $\begin{array}{c}0.170^{* * *} \\
(9.84)\end{array}$ & $\begin{array}{c}0.116^{* *} \\
(2.36)\end{array}$ & $\begin{array}{c}0.165^{* *} \\
(2.48)\end{array}$ \\
\hline Scand. & -- & -- & $\begin{array}{c}0.024^{* * *} \\
(3.57)\end{array}$ & $\begin{array}{c}0.043^{* * *} \\
(4.88)\end{array}$ & $\begin{array}{c}0.028^{* * *} \\
(4.28)\end{array}$ & $\begin{array}{c}0.049^{* * *} \\
(5.70)\end{array}$ & $\begin{array}{l}-0.036 \\
(-1.34)\end{array}$ & $\begin{array}{l}-0.064 * \\
(-1.75)\end{array}$ \\
\hline Overall $\mathbf{R}^{2}$ & $14.69 \%$ & $18.66 \%$ & $16.30 \%$ & $20.96 \%$ & $20.17 \%$ & $24.99 \%$ & $18.54 \%$ & $25.49 \%$ \\
\hline
\end{tabular}




\begin{tabular}{|l|c|c|c|c|c|c|c|c|}
\hline Obs. & 186,498 & 186,477 & 191,278 & 191,246 & 191,278 & 191,246 & 8,133 & 8,129 \\
\hline Firms & 46,453 & 46,450 & 47,339 & 47,334 & 47,339 & 47,334 & 4,687 & 4,684 \\
\hline & $13,886^{* * *}$ & $17,565^{* * *}$ & $14,690^{* * *}$ & $19,395^{* * *}$ & $17,920^{* * *}$ & $23,325^{* * *}$ & $1,173^{* * *}$ & $1,788^{* * *}$ \\
\hline
\end{tabular}

Table 9: Robustness to SIC inclusion

PANEL A: Prevalence of SIC Codes By Country

\begin{tabular}{|l|c|c|c|c|c|c|}
\hline \multirow{2}{*}{ Country } & \multicolumn{5}{|c|}{ US SIC Codes (one digit level) } \\
\hline Austria & $\mathbf{1}$ & $\mathbf{2}$ & $\mathbf{3}$ & $\mathbf{5}$ & $\mathbf{7}$ \\
\hline Finland & $13.06 \%$ & $19.91 \%$ & $13.38 \%$ & $1.02 \%$ & $49.68 \%$ & $2.94 \%$ \\
\hline France & $11.30 \%$ & $20.96 \%$ & $8.18 \%$ & $2.83 \%$ & $50.45 \%$ & $6.28 \%$ \\
\hline Germany & $9.99 \%$ & $23.65 \%$ & $11.95 \%$ & $0.93 \%$ & $44.46 \%$ & $9.01 \%$ \\
\hline Greece & $8.05 \%$ & $31.50 \%$ & $7.33 \%$ & $1.08 \%$ & $48.42 \%$ & $3.62 \%$ \\
\hline Ireland & $11.38 \%$ & $27.17 \%$ & $12.88 \%$ & $6.23 \%$ & $38.27 \%$ & $4.07 \%$ \\
\hline Italy & $13.02 \%$ & $20.10 \%$ & $6.94 \%$ & $4.17 \%$ & $42.13 \%$ & $13.64 \%$ \\
\hline Portugal & $19.93 \%$ & $21.49 \%$ & $7.13 \%$ & $1.04 \%$ & $47.66 \%$ & $2.76 \%$ \\
\hline Spain & $3.23 \%$ & $19.68 \%$ & $12.62 \%$ & $0.44 \%$ & $52.43 \%$ & $6.60 \%$ \\
\hline Sweden & $13.61 \%$ & $19.03 \%$ & $6.54 \%$ & $1.19 \%$ & $51.83 \%$ & $7.80 \%$ \\
\hline
\end{tabular}


PANEL B: Prevalence of SIC Codes By Legal Family

\begin{tabular}{|l|c|c|c|c|c|c|}
\hline & \multicolumn{7}{|c|}{ US SIC Codes (one digit level) } \\
\hline Legal Family & $\mathbf{1}$ & $\mathbf{2}$ & $\mathbf{3}$ & $\mathbf{4}$ & $\mathbf{5}$ & $\mathbf{7}$ \\
\hline Common & $12.96 \%$ & $20.36 \%$ & $7.16 \%$ & $4.24 \%$ & $41.99 \%$ & $13.29 \%$ \\
\hline French & $9.45 \%$ & $19.65 \%$ & $8.05 \%$ & $0.83 \%$ & $53.81 \%$ & $8.21 \%$ \\
\hline German & $10.42 \%$ & $22.83 \%$ & $11.96 \%$ & $1.08 \%$ & $45.82 \%$ & $7.89 \%$ \\
\hline Scandinavian & $9.08 \%$ & $17.68 \%$ & $8.35 \%$ & $1.80 \%$ & $55.25 \%$ & $7.84 \%$ \\
\hline
\end{tabular}

PANEL C: Impact on Findings from SIC Fixed-Effects Models

\begin{tabular}{|c|c|}
\hline Key Variable & Comparison with reported results (Tables $2-8$ ) \\
\hline CRED (1996) & $\begin{array}{l}\text { Basic findings from Tables } 2 \text { and } 3 \text { hold-dummies derived from } \\
\text { CRED inconsistent }\end{array}$ \\
\hline CRED components & $\begin{array}{l}\text { CRED-C still consistently positive and significant (others negative or } \\
\text { unstable) }\end{array}$ \\
\hline Tangibility & Maintains strongly positive coefficient (high significance) \\
\hline $\mathrm{ROA}$ & Maintains strongly negative coefficient (high significance) \\
\hline Asset Specificity & Not able to test this (specificity is an artifact of industry code) \\
\hline Listed & $\begin{array}{l}\text { Negative relationship to leverage for common law, but positive for } \\
\text { others; inconsistent sign when including CRED-A-D; negative and } \\
\text { (generally) significant for matched sample (Table 6); negative and } \\
\text { significant when holding for efficiency }\end{array}$ \\
\hline Legal Origin & $\begin{array}{l}\text { Findings related to legal family variation for firm-level determinants of } \\
\text { leverage hold (Table 4) }\end{array}$ \\
\hline Efficiency & $\begin{array}{l}\text { Findings hold—efficiency coefficient positive, stable, and } \\
\text { highlysignificant }\end{array}$ \\
\hline
\end{tabular}

